\title{
Convolvulaceae em remanescentes de Floresta Ombrófila Densa, Rio de Janeiro, Brasil ${ }^{1}$
}

\author{
Convolvulaceae in Dense Ombrophilous Forest remnants in Rio de Janeiro, Brazil
}

\author{
Ana Luiza de Oliveira Moura ${ }^{2,4}$ \& Marli Pires Morim ${ }^{3}$
}

\begin{abstract}
Resumo
O presente trabalho teve como objetivo o levantamento florístico e o tratamento taxonômico de Convolvulaceae em três remanescentes de Floresta Ombrófila Densa do Estado do Rio de Janeiro: Parque Nacional do Itatiaia (PNI), Parque Nacional da Serra dos Órgãos (Parnaso) e Reserva Biológica de Poço das Antas (Rebio). Foram realizadas consultas a herbários, expedições científicas às áreas de estudo e identificação taxonômica dos espécimes coletados. Os resultados obtidos abrangem chave para identificação das espécies, diagnoses, comentários, ilustrações, e habitat. Foram registrados cinco gêneros, 33 espécies e uma variedade. Cinco espécies são endêmicas da Floresta Atlântica. O número e tipos de estigma, lâmina foliar, fruto e indumento foram os principais caracteres diagnósticos para os táxons estudados. Dentre as espécies estudadas $90 \%$ são herbáceas e $31(86 \%)$ de hábito volúvel, a maioria ascendendo em indivíduos com reduzida circunferência (1-10 cm). A maior riqueza de espécies foi observada para o Parnaso (23), seguido do PNI (15) e da Rebio (11). A Floresta Montana se mostrou a formação preferencial dos táxons, com a ocorrência de 12 espécies. Palavras-chave: Floresta Atlântica, composição florística, trepadeiras, taxonomia, conservação.
\end{abstract}

\begin{abstract}
The present study had the goal of carrying out a floristic inventory and taxonomic treatment of Convolvulaceae in three Dense Ombrophilous Forest remnants in the State of Rio de Janeiro: Itatiaia National Park (Parque Nacional do Itatiaia-PNI), Serra dos Órgãos National Park (Parque Nacional da Serra dos Órgãos-Parnaso), Poço das Antas Biological Reserve (Reserva Biológica de Poço das Antas-Rebio). Herbaria were consulted, scientific expeditions to the study area were carried out and the taxonomy of collected species was identified. The results were able to cover the identification of species, diagnoses, commentary, illustrations, and habitat. The survey found five genera, 33 species and one variety. Five species are endemic to the Brazilian Atlantic Rainforest. The number and types of stigma, leaf lamina, fruit and indumentum were the main characteristics identified for the studied taxa. Among the studied species, $90 \%$ are herbaceous and $31(86 \%)$ have a voluble habit, the majority resulting in individuals with a low circumference $(1-10 \mathrm{~cm})$. The greatest variety of species was observed for Parnaso (23), followed by PNI (15) and finally by Rebio (11). The montane Forest showed greater formation of taxa, with the occurrence of 12 species.
\end{abstract}

Key words: Atlantic Rainforest, floristic composition, vines, taxonomy, conservation.

\section{Introdução}

O estado do Rio de Janeiro abrange cerca de 807.000 hectares de Floresta Atlântica, o que representa aproximadamente $19,6 \%$ de sua cobertura florestal original (S.O.S. Mata Atlântica/ INPE 2009). Os remanescentes florestais fluminenses são representados majoritariamente pela Floresta Ombrófila Densa que se concentra, principalmente, sobre as duas principais cadeias montanhosas do estado, a Serra do Mar e a Serra da Mantiqueira. Mesmo drasticamente reduzidos, estes remanescentes florestais constituem juntamente com as demais áreas remanescentes desta formação,

\footnotetext{
${ }^{1}$ Parte da dissertação de Mestrado da primeira autora apresentada ao Programa de Pós-Graduação em Botânica do Jardim Botânico do Rio de Janeiro, RJ, Brasil.

${ }^{2}$ Habtec Engenharia Sanitária e Ambiental Ltda, Av. Treze de Maio 13 Grupo 1.508, 20031-901, Rio de Janeiro, RJ, Brasil.

${ }_{3}^{3}$ Instituto de Pesquisas Jardim Botânico do Rio de Janeiro, R. Pacheco Leão 915, 22460-030, Rio de Janeiro, RJ, Brasil.

${ }^{4}$ Autor para correspondência: analuizaomoura@gmail.com
} 
centros de diversidade e endemismo de diversos grupos de plantas (Stehmann et al. 2009; Werneck et al. 2011).

Ainda que muitos esforços tenham sido investidos para se conhecer a flora vascular fluminense, análises para espécies de hábito trepador ainda são escassas (Vaz \& Vieira 1994; Lima et al. 1997; Barros et al. 2009). Entretanto, este grupo de plantas representa aproximadamente 22,4\% da flora vascular da Floresta Ombrófila Densa do Rio de Janeiro, contemplando 53 famílias e 169 gêneros (Vaz 1992). Dentre as famílias que compõem a sinúsia de espécies trepadeiras na flora vascular fluminense Convolvulaceae destaca-se por contemplar um número expressivo de espécies volúveis, sendo assinalados sete gêneros (Anisea, Bonamia, Dichondra, Evolvulus, Ipomoea, Jacquemontia e Merremia) e 43 espécies para o estado do Rio de Janeiro (Falcão \& Falcão 1979).

A distribuição de Convolvulaceae é principalmente tropical, mas a família também ocorre em climas subtropicais e temperados (Ribeiro \& Bianchini 1999). Segundo Gentry (1991) Convolvulaceae constitui uma das famílias mais ricas em espécies escaladoras nas Américas, onde o Brasil destaca-se pela ocorrência do grande número de táxons nos diferentes domínios fitogeográficos do país: 22 gêneros e 403 espécies das quais 180 são endêmicas da flora brasileira (Simão-Bianchini et al. 2015). Para as áreas de Floresta Atlântica foram registrados 15 gêneros e 150 espécies, sendo 14 espécies citadas como endêmicas desta faixa florestal, com ocorrência principalmente nas formações de Floresta Ombrófila Densa (Simão-Bianchini et al. 2015).

Considerando a escassez de informações sobre a família Convolvulaceae em áreas de Floresta Ombrófila Densa, o presente trabalho teve como objetivo ampliar o conhecimento sobre a riqueza e diversidade taxonômica da família através do levantamento em áreas remanescentes desta fitofisionomia no Estado do Rio de Janeiro e consequentemente contribuir para o incremento de informações sobre a sinúsia de espécies trepadeiras que ocorrem nestas áreas.

\section{Material e Métodos}

Foram selecionados três remanescentes de Floresta Ombrófila Densa (FOD) do Estado do Rio de Janeiro, localizados no Corredor de Biodiversidade da Serra do Mar: o Parque
Nacional de Itatiaia, o Parque Nacional da Serra dos Órgãos e a Reserva Biológica de Poço das Antas (Fig.1). Estes remanescentes se encontram em diferentes graus de fragmentação e de estágios sucessionais.

\section{Parque Nacional do Itatiaia (PNI)}

O Parque Nacional do Itatiaia está localizado na divisa entre os estados do Rio de Janeiro e Minas Gerais, na Serra da Mantiqueira. Fica a sudoeste do Rio de Janeiro, nos municípios de Resende e Itatiaia, e ao sul de Minas Gerais, nos municípios de Bocaina de Minas e Itamonte $\left(22^{\circ} 19^{\prime}\right.$ e $22^{\circ} 45^{\prime} \mathrm{S}$ e $44^{\circ} 15^{\prime}$ e $\left.44^{\circ} 50^{\prime} \mathrm{W}\right)$, abrangendo uma área de 28.084,100 hectares (ICMBIO 2012). Os aspectos relacionados à geomorfologia, hidrografia, clima e vegetação da área foram descritos em Morim (2006).

\section{Parque Nacional da Serra dos Órgãos (Parnaso)}

O Parnaso ocupa posição central no Corredor de Biodiversidade da Serra do Mar (Aguiar et al. 2005), e situa-se entre as coordenadas geográficas $22^{\circ} 52^{\prime}$ e $22^{\circ} 54^{\prime}$ Sul e $42^{\circ} 09^{\prime}$ e $45^{\circ} 06^{\prime}$ Oeste. Abrange uma área de 10.653 hectares que se insere nos municípios de Guapimirim, Magé, Petrópolis e Teresópolis. As informações sobre clima, pluviosidade, relevo, hidrografia e sobre as faixas altitudinais das fitofisionomias da Floresta Atlântica do Parnaso foram consultadas, respectivamente, em Cronemberger \& Castro (2007), Davis \& Naghettini (2000) e IBDF \& FBCN (1980).

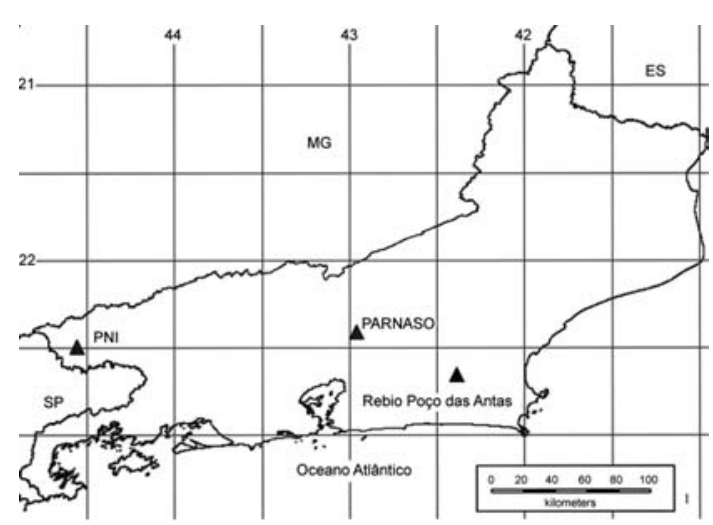

Figura 1 - Localização das áreas de estudo no estado do Rio de Janeiro.

Figure 1 - Location of the study areas in the State of Rio de Janeiro. 


\section{Reserva Biológica de Poço das Antas (Rebio)}

A Rebio localiza-se no município de Silva Jardim em extensa planície da região central do estado (22³0'e $22^{\circ} 33^{\prime} \mathrm{S}, 42^{\circ} 19^{\prime} \mathrm{W}$ ), com área aproximada de 5.000 hectares sob influência direta da bacia hidrográfica do rio São João (Lima et al. 2006). Os aspectos relacionados à geomorfologia, hidrografia, clima e vegetação foram descritos em Lima et al. (2006).

\section{Levantamento florístico}

O levantamento florístico baseou-se em consultas à bibliografia, às coleções dos herbários HB, RB, RBR e SP (segundo Thiers, continuamente atualizado) e expedições de campo realizadas no período de abril de 2008 a agosto de 2009.

A coleta de exemplares férteis foi realizada adotando-se o método de caminhamento livre (Filgueiras et al. 1994), ao longo das estradas e trilhas das unidades estudadas, priorizando-se as bordas florestais, tendo sido considerado como borda apenas a interface entre os ambientes florestados e não florestados (Harper et al. 2005). Para os espécimes coletados foram registrados dados sobre o hábito, fenologia, altitude do sítio de coleta e no caso das espécies escandentes foram tomados os valores da circunferência a altura do peito (CAP) dos forófitos em que os espécimes estavam ascendendo. Os exemplares foram processados seguindo-se as técnicas de herborização (Guedes-Bruni et al. 2002) e foram depositados no herbário RB.

Os valores obtidos para os CAP dos forófitos foram agrupados em cinco classes de circunferência: $1-10 \mathrm{~cm}, 11-20 \mathrm{~cm}, 21-30 \mathrm{~cm}$, $31-40 \mathrm{~cm}$ e $>40 \mathrm{~cm}$.

O conceito de trepadeira foi adotado de Gentry (1991). Quanto à morfologia do caule as espécies foram divididas em duas categorias: liana - plantas com crescimento secundário pronunciado resultando em caules maiores que $1 \mathrm{~cm}$ diâm. e trepadeira herbácea - plantas com crescimento secundário incipiente resultando em caules menores que $1 \mathrm{~cm}$ diâm.

\section{Tratamento taxonômico}

A identificação dos exemplares, coletados e aqueles indeterminados nas coleções, baseou-se em bibliografia especializada (O’Donell 1952; Austin 1975; Falcão 1957, 1974, 1977; Falcão
\& Falcão 1979; Austin \& Cavalcante 1982; Acevedo-Rodrígues 2005), no exame das coleções depositadas nos herbários consultados, e posterior revisão da Dra. Rosangela Simão-Bianchini, especialista do grupo. As descrições das espécies priorizaram as características fundamentais para o reconhecimento do respectivo táxon nas áreas estudadas, considerando-se as peculiaridades de cada gênero tratado. A distribuição geográfica dos táxons e a ocorrência nos biomas e respectivas formações vegetacionais do Brasil foi baseada em Simão-Bianchini et al. (2015). As informações sobre o habitat na Floresta Atlântica do Estado do Rio de Janeiro foram complementadas, quando necessário com dados obtidos em bibliografia, nas coleções de herbários e das observações de campo.

Na ausência de exemplares com estruturas reprodutivas, provenientes das áreas de estudo, as descrições foram baseadas em exemplares oriundos de outras áreas, os quais foram citados como material adicional.

\section{Resultados e Discussão}

As Convolvulaceae estão representadas nas três áreas estudadas por cinco gêneros, 33 espécies e uma variedade (Tab. 1). Em relação às áreas estudadas destaca-se o Parnaso como área que concentra a maior riqueza de espécies, 23 táxons que ocorrem desde a floresta Submontana até a Montana. Ressalta-se que 11 das espécies catalogadas no presente estudo foram registradas apenas nesta área (Tab. 1). Para o PNI foram registradas 16 espécies (Tab.1), que se distribuem, predominantemente, na faixa entre 600 e 800 m.s.m, dentre estas, quatro apresentaram ocorrência exclusiva a esta Unidade de Conservação e 12 foram comuns às demais áreas de estudo. Na Rebio de Poço das Antas foram registradas 11 espécies (Tab. 1), cinco de ocorrência exclusiva e seis comuns às demais áreas.

A formação Montana concentrou a maior riqueza de táxons (11spp.), seguida da Submontana (8 spp). Dentre as formações campestres, destacase a Capoeira Aluvial para a qual foi registrado o total de quatro espécies. Os demais valores para distribuição das espécies por tipologia vegetacional se encontram na Tabela 1.

Veloso et al. (1991) citam que as trepadeiras herbáceas são mais abundantes na Floresta Ombrófila Densa Submontana do que nas 
Tabela 1 - Lista florística de Convolvulaceae em remanescentes de Floresta Ombrófila Densa do estado do Rio de Janeiro. Table 1 - Floristic checklist of Convolvulaceae in Dense Ombrophilous Forest remnants in the State of Rio de Janeiro.

\begin{tabular}{|c|c|c|c|c|c|}
\hline Espécies & Parnaso & PNI & Rebio & Formação vegetacional & Hábito ${ }^{1}$ \\
\hline Convolvulus crenatifolius & $\mathrm{x}$ & & & FOD montana & HERB / VOL \\
\hline \multicolumn{6}{|l|}{ DICHONDRA } \\
\hline Dichondra macrocalyx & $\mathrm{x}$ & & & FOD montana & $\begin{array}{r}\text { H E R B } \\
\text { RAST }\end{array}$ \\
\hline Dichondra parvifolia & & $\mathrm{x}$ & & FOD montana & HERB/RAST \\
\hline Dichondra micrantha & $\mathrm{x}$ & & & FOD montana/submontana & HERB/RAST \\
\hline Dichondra sericea & & $\mathrm{x}$ & & FOD montana & HERB/RAST \\
\hline \multicolumn{6}{|l|}{ IPOMOEA } \\
\hline Ipomoea alba & $\mathrm{x}$ & & & FOD montana & $\mathrm{HERB/VOL}$ \\
\hline Ipomoea aristolochiaefolia & $\mathrm{x}$ & & & FOD montana & HERB/VOL \\
\hline Ipomoea batatas & $\mathrm{x}$ & & & FOD montana & RAST/VOL \\
\hline Ipomoea cairica & $\mathrm{x}$ & $\mathrm{x}$ & & FOD montana/submontana & HERB/VOL \\
\hline Ipomoea cynanchifolia* & & & $\mathrm{x}$ & Campo antrópico & $\mathrm{HERB} / \mathrm{VOL}$ \\
\hline Ipomoea daturaefolia & $\mathrm{x}$ & & & FOD montana & HERB/VOL \\
\hline Ipomoea grandifolia & $\mathrm{x}$ & & & FOD montana & HERB / VOL \\
\hline Ipomoea hederifolia & $\mathrm{x}$ & $\mathrm{x}$ & & FOD montana & HERB/VOL \\
\hline Ipomoea indica & $\mathrm{x}$ & $\mathrm{x}$ & & FOD montana & $\mathrm{HERB/VOL}$ \\
\hline Ipomoea indivisa & $\mathrm{x}$ & & & FOD montana & $\mathrm{HERB} / \mathrm{VOL}$ \\
\hline Ipomoea phyllomega & $\mathrm{x}$ & $\mathrm{x}$ & $\mathrm{x}$ & $\begin{array}{l}\text { FOD submontana/Capoeira } \\
\text { submontana/Formação pioneira } \\
\text { com influência fluvial }\end{array}$ & LENH/VOL \\
\hline Iротоеа purpurea & $\mathrm{x}$ & $\mathrm{x}$ & & FOD montana & HERB / VOL \\
\hline Ipomoea ramosíssima* & $\mathrm{x}$ & $\mathrm{x}$ & & FOD montana/submontana & HERB / VOL \\
\hline Ipomoea regnellii* & & $\mathrm{x}$ & & FOD montana & HERB / VOL \\
\hline Ipomoea saopaulista & $\mathrm{x}$ & $\mathrm{x}$ & & FOD montana & HERB / VOL \\
\hline Ipomoea syringaefolia & $\mathrm{x}$ & & & FOD montana & HERB / VOL \\
\hline Ipomoea tiliaceae & & & $\mathrm{x}$ & Capoeira aluvial & HERB / VOL \\
\hline Ipomoea triloba & & & $\mathrm{x}$ & Capoeira aluvial & HERB / VOL \\
\hline \multicolumn{6}{|l|}{ JACQUEMONTIA } \\
\hline Jacquemontia blanchetii* & & $\mathrm{x}$ & & FOD montana & HERB / VOL \\
\hline Jacquemontia densiflora & $\mathrm{x}$ & $\mathrm{x}$ & & FOD montana & HERB / VOL \\
\hline Jacquemontia holosericea & & $\mathrm{x}$ & $\mathrm{x}$ & Capoeira aluvial & HERB / VOL \\
\hline Jacquemontia martii & $\mathrm{x}$ & & & FOD montana & HERB / VOL \\
\hline Jacquemontia velutina & $\mathrm{x}$ & & $\mathrm{x}$ & Capoeira aluvial & HERB / VOL \\
\hline
\end{tabular}




\begin{tabular}{|c|c|c|c|c|c|}
\hline Espécies & Parnaso & PNI & Rebio & Formação vegetacional & Hábito ${ }^{1}$ \\
\hline \multicolumn{6}{|l|}{ MERREMIA } \\
\hline Merremia cissoides* & & & $\mathrm{x}$ & Campo antrópico & HERB / VOL \\
\hline Merremia dissecta & & & $\mathrm{x}$ & $\begin{array}{c}\text { FOD submontana e } \\
\text { Capoeira submontana }\end{array}$ & HERB / VOL \\
\hline Merremia dissecta var. edentata & $\mathrm{x}$ & $\mathrm{x}$ & $\mathrm{x}$ & $\begin{array}{l}\text { FOD montana/submontana, } \\
\text { Capoeira aluvial e formação } \\
\text { pioneira com influência aluvial }\end{array}$ & HERB / VOL \\
\hline Merremia macrocalyx & $\mathrm{x}$ & $\mathrm{x}$ & & FOD montana & HERB / VOL \\
\hline Merremia tuberosa & $\mathrm{x}$ & & $\mathrm{x}$ & FOD submontana & LENH / VOL \\
\hline Merremia umbellata* & & $\mathrm{x}$ & $\mathrm{x}$ & $\begin{array}{l}\text { FOD montana, Capoeira aluvial } \\
\text { e Capoeira submontana }\end{array}$ & HERB / VOL \\
\hline Total de espécies por área & 23 & 16 & 10 & & \\
\hline Total de espécies nas áreas estudadas & 33 & & & & \\
\hline
\end{tabular}

demais formações. Contudo, os dados obtidos para Convolvulaceae sugerem que os avanços nos processos de fragmentação, podem estar influenciando na composição florística das formações florestais em áreas de maior altitude, através do aumento de sítios propícios para ocorrência de espécies associadas aos ambientes perturbados a exemplo da família em questão.

Muitas espécies desta família são citadas na literatura como plantas daninhas ou invasoras de culturas (Kissman \& Groth 1992; Simão-Bianchini 1998; Lorenzi 2008), sendo frequentemente associadas a ambientes antropizados. Porém, dentro de seu ambiente natural, estas espécies podem atuar de forma benéfica, contribuindo ecologicamente para o processo de sucessão primária em áreas degradadas, através da disponibilização de nutrientes, proteção do solo contra erosão, além da retenção de umidade e redução do aquecimento do solo através de sua cobertura morta (Deuber 1992). Desta forma a presença deste grupo de plantas nos domínios de Unidades de Conservação deve ser analisada com cautela considerando a função ecológica que as mesmas exercem em ambientes nativos.

Quanto à circunferência dos caules dos forófitos foram obtidas as seguintes médias por unidade: 11,16 cm de CAP para Rebio Poço das
Antas, 13,26 cm para o PNI e 21,23 cm para o Parnaso. Dentre os 49 espécimes coletados, 31 (63\%) estavam ascendendo em indivíduos pertencentes à classe de menor circunferência (1-10 $\mathrm{cm})$, contrastando com apenas três espécimes que ocorreram na classe de maior circunferência ( $>40$ $\mathrm{cm}$ ) (Fig. 2). Estes dados reforçam a teoria de que as trepadeiras herbáceas ocorrem, preferencialmente, em clareiras e bordas florestais, considerando-se que nestes sítios existe maior oferta de suportes com baixas circunferências (Gentry 1991; Lima et al. 1997; Engel et al. 1998). O forófito com maior valor de circunferência atingiu $92 \mathrm{~cm}$, o que corrobora os resultados obtidos por Putz (1984), onde o autor constatou que plantas com o tipo de crescimento volúvel têm sucesso em ascender em forófitos com diâmetro até $120 \mathrm{~cm}$.

\section{Tratamento taxonômico}

A análise do tratamento taxonômico demonstrou que os seguintes caracteres são diagnósticos para a circunscrição e reconhecimento das espécies: tipo de indumento, composição e forma da folha, tipo de inflorescência, forma da sépala, forma da corola, forma e número de estigmas e tipo e forma de fruto. A distribuição dos táxons para o Brasil está disponível em SimãoBianchini et al. 2015. 


\section{Chave para identificação das espécies}

1. Ervas prostradas; folhas reniformes; estilete bífido, estigmas capitados; fruto esquizocarpáceo, sementes 2 . 2. Tricomas bífidos, acinzentados.

3. Indumento densamente pubescente em ambas as faces da lâmina foliar; sépala com base truncada e ápice agudo; corola alva

2. Dichondra macrocalyx

3'. Indumento seríceo-tomentoso na face abaxial das lâminas foliares tornando-as discolores; sépala com base atenuada e ápice obtuso a acuminado; corola esverdeada a amarelada ........

2'. Tricomas simples, dourados.

3. Dichondra micrantha

4. Lâminas com indumento seríceo-tomentoso; sépalas com indumento pubescente em ambas as faces

4. Dichondra parvifolia

4'. Lâminas com indumento pubescente a glabrescente; sépalas com indumento piloso na face externa

5. Dichondra sericea

1'. Plantas volúveis ou ocasionalmente ervas rastejantes com as porções apicais volúveis; folhas não reniformes; estilete inteiro, raro bifurcado no ápice (Ipomoea cairica), estigmas filiformes, globosos, bilobados ou oval-planos; cápsulas septifraga, sementes 3-4.

5. Estigmas filiformes; área mesopétala prolongada formando apículos no ápice da corola...... 1. Convolvulus crenatifolius

5'. Estigmas globosos, bilobados, ovoides ou ovais-planos; área mesopétala não prolongada no ápice da corola.

6. Estigmas oval-planos; fruto 8-valvar.

7. Inflorescência em cimas densas, compactas.

7'. Inflorescência em cimas laxas.

8. Plantas com indumento tomentoso a fulvo-velutino.

9. Sépalas nitidamente desiguais, frequentemente uma externa menor, ápice arredondado, obtuso ou retuso. 26. Jacquemontia holosericea

9'. Sépalas levemente desiguais, ápice agudo a acuminado, apiculado ........ 28. Jacquemontia velutina

8'. Plantas com indumento pubescente a glabrescente.

10. Sépalas com ápice redondo a obtuso, margem ocasionalmente ciliada .. 24. Jacquemontia blanchetti

10'. Sépalas de ápice agudo a acuminado, margem não ciliada

27. Jacquemontia martii

6'. Estigmas globosos, bilobados ou ovoides; fruto 4-valvar.

11. Folhas com estrutura estipulácea palmatissectas na base do pecíolo; estigmas ovoides 9. Ipomoea cairica

11'. Folhas sem estrutura estipulácea; estigmas globosos ou bilobados.

12. Estigmas 2.

13. Folhas compostas ou quando simples 5-7 lobadas; cálice acrescente.

14. Folhas compostas, digitadas; cápsulas globosas.

15. Tricoma glandular presente; lâminas foliares com margem denteada, raro sinuada, venação craspedódroma.

29. Merremia cissoides

15'. Tricoma glandular ausente; lâminas foliares com margem lisa, venação broquidódroma

31. Merremia macrocalyx

14'. Folhas simples, 5-7 lobadas; cápsulas ovoides.

16. Trepadeira lenhosa, glabra; corola amarelada; sementes pubescentes com tricomas negros

32. Merremia tuberosa

16'. Trepadeira herbácea, hisurta; corola alva com fauce amarelada; sementes glabras ..30. Merremia dissecta var. edentata 
13'. Folhas simples, em geral cordadas passando a hastadas, sagitadas, deltoides ou 3 lobadas; cálice menor que os frutos.

17. Corola campanulada.

18. Inflorescência em dicásio.

19. Sépalas com ápice de mucronado a aristado; fruto globoso.

19'. Sépalas com ápice obtuso a levemente retuso; fruto ovoide

18. Ipomoea ramosissima

18'. Inflorescência em cimas.

10. Ipomoea cynanchifolia

20. Cimas umbeliformes, frutos ovoides.

Merremia umbellata

20'. Cimas dicasiais, frutos globosos.

21. Corola rosada ou purpurea; ovário hirsuto, semente com a porção médio apical glabra

12. Ipomoea grandifolia

21'. Corola alva ou creme esverdeada; ovário glabro, semente com a porção médio apical com tricomas dourados.

21. Ipomoea syringaefolia

17'. Corola infundibuliforme ou hipocrateriforme.

22. Caule com emergências escamiformes, corola hipocrateriforme, estames exsertos........

6. Ipomoea alba

22'. Caule sem emergências escamiformes, corola infundibuliforme, estames inclusos.

23. Ervas rastejantes com ramos apicais volúveis, ovário hirsuto

8. Ipomoea batatas

23’. Plantas volúveis, ovário glabro.

24. Inflorescência em dicásio; fruto ovoide

19. Ipomoea regnelli

24'. Inflorescência em cimas, fruto globoso.

25. Sementes hisurtas, com tricomas longos (ca. 1,5 cm compr.) frouxamente inseridos na porção dorso-apical da testa.

16. Ipomoea phyllomega

25'. Sementes pilosas, com tricomas curtos $(<1,5 \mathrm{~cm}$ compr.) revestindo toda a superfície da testa .....

11. Ipomoea daturiflora

12'. Estigma único.

26. Estigma globoso.

27. Corola avermelhada, estames exsertos, sementes pubescentes.

13. Ipomoea hederifolia

27'. Corola rósea, lilás ou purpúrea, estames inclusos, sementes glabras.

28. Corola campanulada, ovário hirsuto

23. Ipomoea triloba

28'. Corola infundibuliforme, ovário glabro.

29. Sépalas lanceoladas, com indumento adpresso piloso a pubescente, esparso

14. Ipomoea indica

29’. Sépalas oblongo-lanceoladas, com indumento híspido adensado na porção basal da face externa

17. Ipomoea purpurea

26'. Estigma bilobado.

30. Cálice com sépalas do mesmo tamanho, base dos filetes glabra, ovário piloso, fruto ovoide 7. Ipomoea aristolochifolia

30'. Cálice com sépalas de tamanhos diferentes, base dos filetes pubescente, ovário glabro, fruto globoso.

31. Plantas com indumento pubescente ou glabrescente.

32. Sépalas com rostro subapical ca. $2 \mathrm{~cm}$; fruto glabro

15. Ipomoea indivisa

32'. Sépalas sem rostro; fruto com tricomas esparsos externamente

22. Ipomoea tiliaceae

31'. Plantas com indumento densamente tomentoso na face abaxial das lâminas foliares.... 20. Ipomoea saopaulista 


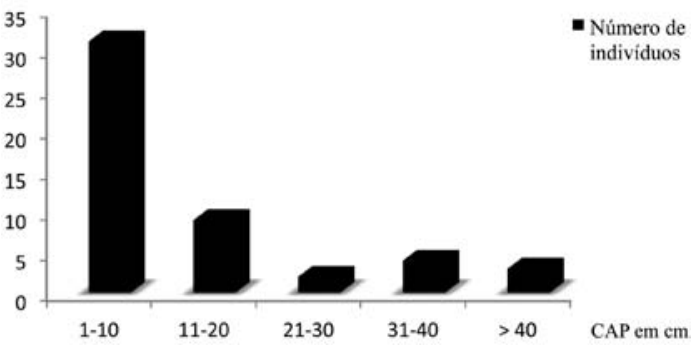

Figura 2 - Número de indivíduos de Convolvulaceae por classe de circunferência dos forófitos.

Figure 2 - Number of individuals of Convolvulaceae by class of the circumference of the phorophytes.

\section{Descrição das espécies}

Convolvulus crenatifolius Ruiz \& Pav. Fl. Peruv.

2: 10, t. 118, fig. a. 1799.

Figs. 3a-c; 4a-h

Trepadeira herbácea. Lâmina simples 2,5-6,5

$\times 1-2,5 \mathrm{~cm}$, ovada, de lanceolada a sagitada, base hastata, sagitada ou auriculada, ápice agudo a mucronulado, margem inteira a ondulada. Inflorescência em dicásio simples. Flores com cálice com 2 sépalas, frequentemente maiores e mais estreitas, $1-1,2 \times 0,1-0,2 \mathrm{~cm}$, pilosas, obovadas a lanceoladas e 3 sépalas internas menores, 5-7 $\times$ 2-3 mm pubescentes na face externa, ovadas a obovadas; corola alva, 1,3-2,5 cm, campanulada, área mesopétala pilosa externamente e prolongada em apículos no ápice da corola; ovário súpero, estilete inteiro, estigma filiforme. Cápsula septífraga 5-7 × 6-8 mm, globosa, glabra, cálice acrescente; semente 3-4 × 1-2 mm, glabra.

Material examinado: Petrópolis, 1944, fl., O.C. Góes 1109 (RB).

Material adicional examinado: BRASIL. MINAS GERAIS: Carandaí, Crespo, 10.I.1948, fl., Duarte 1099 (RB); São Paulo: Cantareira, 5.IX.1941, fl. e fr., L. Constatino 82 (RB).

Convolvulus crenatifolius ocorre predominantemente em formações de Floresta Ombrófila Densa e Floresta Ombrófila Aberta.

A espécie possui como carater diagnóstico a área mesopétala que forma apículos no ápice da corola. As áreas mesopétalas são características da família Convolvulaceae, e segundo Staples (2012) podem fornecer caracteres de significado taxonômico genérico ou específico.

Dichondra J.R. Forst. \& G. Forst. Characteres Generum Plantarum [second edition] 39, pl. 20. 1776.

Figs. 3d-f; 4i-q

Ervas prostradas, folha simples, inteira, membranácea, reniforme, base profundamente cordada a auriculada, ápice truncado, margem inteira, venação basal. Flores solitárias, pediceladas; cálice com sépalas de mesmo tamanho, livres, herbáceas, pubescentes em pelo menos uma das faces, acrescentes no fruto; corola rotácea, com ápice 5-partido, glabra, recoberta pelo cálice; estames iguais, exsertos, glabros; ovário súpero hisurto, tricoma simples, estilete bífido, filiformes, estigmas 2, capitados, papilosos. Fruto indeiscente, esquizocarpáceo, piloso externamente, sementes 2 , glabras.

Falcão (1974) citou quatro espécies representantes do gênero no Brasil e, recentemente, Simão-Bianchini et al. (2015) registraram seis espécies para a flora do país. Quatro das espécies mencionadas pelos autores ocorrem nas áreas estudadas.

O gênero Dichondra, no presente estudo, abrange quatro espécies: $D$. macrocalyx e $D$. micranta que apresentam tricomas bífidos e acinzentados e $D$. parvifolia e $D$. sericea, nas quais os tricomas são simples e dourados.

2. Dichondra macrocalyx Meisn., Fl. Bras. 7: 358. 1869.

Planta pubescente com tricoma bífido, acinzentado. Indumento densamente pubescente em ambas as faces da lâmina foliar e cálice. Lâmina 1-2,3 × 1-2,2 cm. Cálice com sépalas 4-5 × 1-2 mm, lanceolada, base truncada, ápice agudo; corola alva, ca. 2 mm compr. Fruto 2-3 mm compr.; semente ca. $2 \times 1 \mathrm{~mm}$.

Material examinado: Petrópolis, 15.VIII.1944, fl. e fr., O.C. Góes \& Constatino (RB 49776); Guapimirim, Parque Nacional da Serra dos Órgãos, 12.VII.2009, fl. e fr., A.L.O. Moura 49 \& R.S. Nunes (RB).

Material adicional examinado: BRASIL. RIO DE JANEIRO: Rio de Janeiro, Jardim Botânico do Rio de Janeiro, 13.V.1944, fl. e fr., J.G. Kuhlmann (RB 49204).

Dichondra macrocalyx éreferida para formações de Floresta Ombrófila e Campo Limpo, além de áreas antropizadas. $\mathrm{O}$ indumento pubescente em ambas as faces e a coloração alva da corola são os caracteres principais que distinguem $D$. macrocalyx de D.micrantha, na qual as folhas são discolores em consequência do indumento seríceo-tomentoso na face abaxial e a corola apresenta coloração de esverdeada a amarelada.

3. Dichondra micrantha Urb. Symb. Antill. (Urban). 9(2): 243. 1924.

Fig. 4i-k

Planta pubescente a glabrescente com tricomas bífidos, acinzentados. Lâmina 1-2,7 × 1-4,3 cm, indumento seríceo-tomentoso na face abaxial 

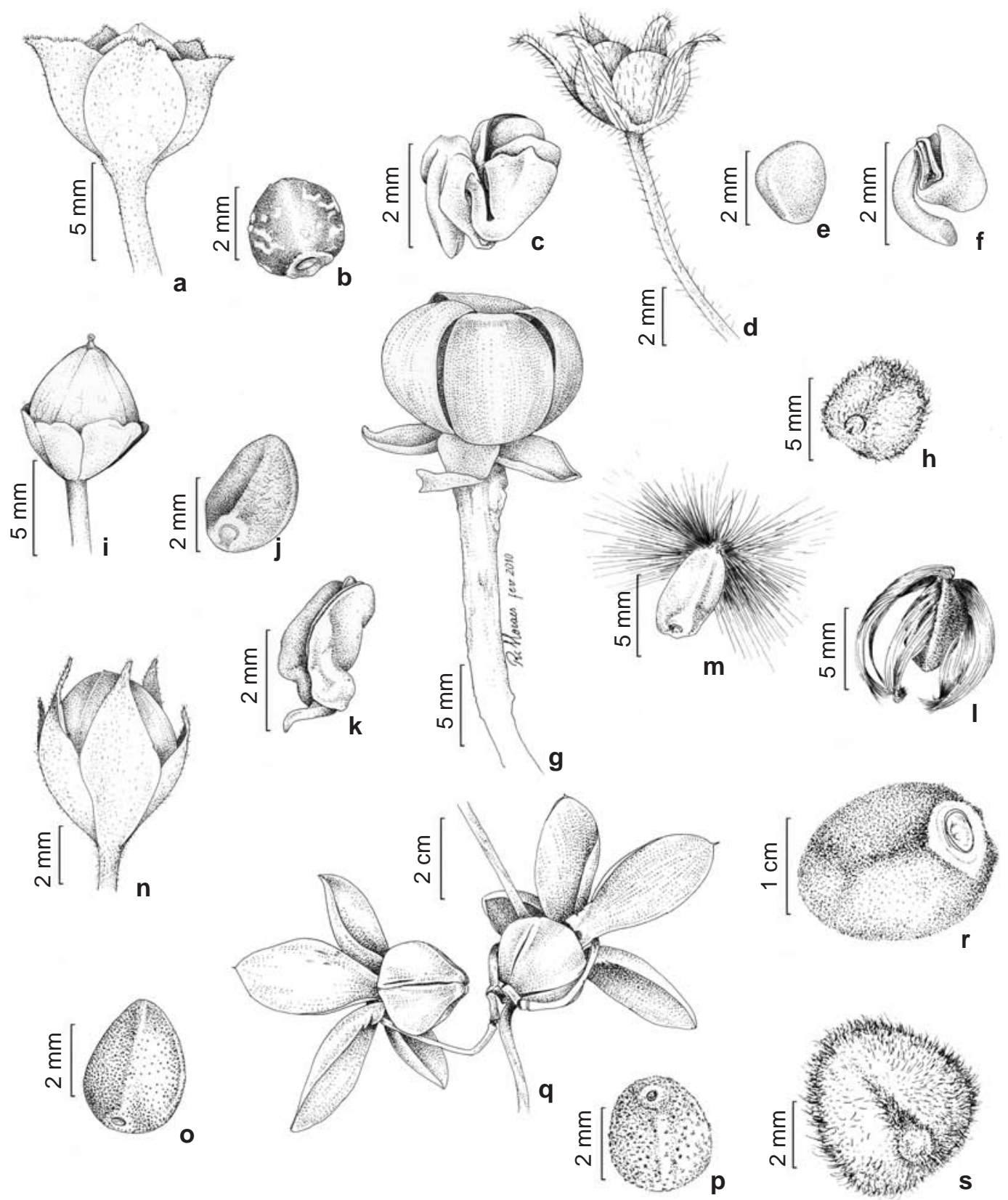

Figura 3 - a-c. Convolvulus crenatifolius Ruiz \& Pav. - a. fruto; b. semente; c. embrião. d-f Dichondra parvifolia Meisn. - d. fruto; e. semente; f. embrião. g,h. Ipomoea cairica (L.) Sweet. - g. fruto; h. semente. i-k Ipomoea cynanchifolia Meisn - i. fruto; j. semente; k. embrião. 1. Ipomoea phyllomega (Vell.) House. - semente. m. Ipomoea syringifolia Meisn. - semente. n,o. Jacquemontia densiflora (Meisn.) Hallier f. - n. fruto; o. semente. p. Merremia cissoides (Lam.) Hallier f. - semente. q. Merremia dissecta - fruto. r. Merremia tuberosa (L.) Rendle - semente. s. Merremia umbellata (L.) Hallier f. - semente. (a, c. Constatino 82; d-f. Brade 20814; g, h. Moura 32; i-k. Moura 66; 1. Moura 51; m. Carauta 2033; n, o. Sucre 2272; p. Moura 56; q. Moura 64; r. Moura et al. 52; s. Trinta 909).

Figure 3 - a-c. Convolvulus crenatifolius Ruiz \& Pav.- a. fruit; b. seed; c. embryo. d-f Dichondra parvifolia Meisn.- d. fruit; e. seed; f. embryo. g,h. Ipomoea cairica (L.) Sweet. - g. fruit; h. seed. i-k. Ipomoea cynanchifolia Meisn - i. fruit; j. seed; k. embryo. 1. Ipomoea phyllomega (Vell.) House. - seed. m. Ipomoea syringifolia Meisn. - seed. n,o. Jacquemontia densiflora (Meisn.) Hallier f. - n. fruit; o. seed. p. Merremia cissoides (Lam.) Hallier f. - seed. q. Merremia dissecta - fruit. r. Merremia tuberosa (L.) Rendle - seed. s. Merremia umbellata (L.) Hallier f. - seed. (a,c. Constatino 82; d-f. Brade 20814; g,h. Moura 32; i-k. Moura 66; 1. Moura 51; m. Carauta 2033; n,o. Sucre 2272; p. Moura 56; q. Moura 64; r. Moura et al. 52; s. Trinta 909). 
tornando-a discolor. Cálice com sépala 3-4 × $1 \mathrm{~mm}$, pubescente na face externa, lanceolada a obovada, base atenuada, ápice obtuso a acuminado; corola de esverdeada a amarelada, 2-3 mm compr. Fruto 3-4 mm compr.; semente ca. $2 \times 1 \mathrm{~mm}$.

Material examinado: Petrópolis, Maria Comprida, 1944, fl. e fr., O.C. Góes 344 (RB).

Material adicional examinado: BRASIL. SÃO PAULO: Serra da Bocaina, 11.V.1957, fl. e fr., A.C. Brade 20932 (RB).

Dichondra micrantha é uma espécie cultivada, largamente utilizada para fins ornamentais, principalmente para formação de tapetes verdes, e em menor escala para fins medicinais. Considerando os usos atribuídos a $D$. micrantha, pode-se presumir que a presença desta espécie em formações naturais de Floresta Ombrófila Densa deve-se, provavelmente, à proximidade de áreas residenciais aos remanescentes florestais analisados. Austin (1998) menciona determinadas atividades antrópicas, dentre elas a comercialização de sementes para práticas de paisagismo, como um dos principais vetores de distribuição de D. micrantha.

4. Dichondra parvifolia Meisn., Fl. Bras. 7:. 1869

Fig. 3d-f

Planta com tricomas simples, dourados a glabrescente. Lâmina 0,5-0,8 × 0,6-1 cm, com indumento seríceo-tomentoso. Cálice com sépala 3-4 × $1 \mathrm{~mm}$, lanceolada, base atenuada, ápice agudo, pubescente em ambas as faces; corola alva, 2-3 mm compr. Fruto 2-3 mm compr.; semente ca. $2 \times 1 \mathrm{~mm}$.

Material examinado: Itatiaia, 28.XII.1938, fl., Markgraf, 3680 (RB).

Material adicional examinado: BRASIL. RIO DE JANEIRO: Pilar, 1960, fl., J.G. Kuhlmann (RB 22515); São Paulo: Serra da Bocaina, 1900 m.s.m, 30.IV.1951, fl. e fr., A.C. Brade 20814 (RB).

Dichondra parvifolia é endêmica da Floresta Atlântica e ocorre com frequência nas formações vegetacionais da Floresta Ombrófila Densa, sendo referida para Campos de Altitude e Floresta Ombrófila Aberta. Possui afinidades com $D$. sericea, da qual se separa pelo indumento seríceotomentoso das folhas e indumento pubescente nas sépalas, enquanto em $D$. sericea as folhas possuem indumento pubescente e as sépalas apresentam indumento piloso apenas na face externa.

\section{Dichondra sericea Sw. Prodr. 54. 1788.}

Fig. 4l-q

Planta com tricomas simples, dourados, em geral glabrescente. Lâmina 0,5-1,5 × 0,7-2,5 cm, pubescente na face abaxial e glabrescente na face adaxial. Calice com sépala 3-4 × $1 \mathrm{~mm}$, pilosa na face externa, ovoide a lanceolada, base atenuada, ápice agudo; corola alva, 2-3 mm compr. Fruto 3-4 mm compr.; semente ca. $2 \times 2 \mathrm{~mm}$.

Material examinado: Itatiaia, 3.III.1937, fl. e fr. A.C. Brade 15586 (RB).

Material adicional examinado: BRASIL. PARANÁ: Capanema, 13.XI.1973, fl. R. Kumarow 45 (RB); Rio Grande do Sul, Jaguarão, 2.XI.1961, fl., E. Pereira 6718 (RB).

Dichondra sericea é conhecida popularmente como orelha-de-rato sendo cultivada em parques e jardins por formar gramados em áreas sombreadas. Segundo Franco et al. (2009) a espécie é cosmopolita e ocorre em regiões quentes e/ou temperadas, principalmente nas Américas. Para as áreas de Floresta Atlântica a espécie é referida para formações de Campos de Altitude.

\section{Ipomoea L.}

Figs. 3g-m; 5

Trepadeiras herbáceas ou lenhosas, raro ervas rastejantes com as porções apicais volúveis. Folha simples, margem inteira a levemente ondulada, ciliada ou não. Inflorescência cima ou dicásio. Flores com sépalas de tamanho iguail ou desigual, imbricadas; corola infundibuliforme, hipocrateriforme ou campanulada; estames desiguais, inclusos ou exsertos, livres, frequentemente com indumento na base do filete; ovário súpero, glabro, piloso ou pubescente, estilete 1 ou 2, inteiro(s) ou raro bifurcado no ápice; estigma 1 ou 2, globoso, bilobado ou ovoide, papiloso. Fruto cápsula septifraga globosa ou ovoide, 4-valvar, cálice persistente, menor que o fruto; sementes 4.

Segundo Gentry (1991), Ipomoea é o segundo maior gênero em número de espécies trepadeiras, depois do gênero Dioscorea (Dioscoriaceae). Simão-Bianchini et al. (2015) registraram 146 espécies para o Brasil, sendo 53 delas endêmicas ao território brasileiro.

\section{Ipomoea alba L. Sp. Pl. 1: 161. 1753.}

Trepadeira herbácea, caule com emergências escamiformes irregulares. Lâmina 5-13 × 3,5-13 cm, discolor, ovada, cordada ou cordado-hastada, inteira ou 3-lobada, base cordada, auriculada a truncada-auriculada, ápice agudo a caudado. Flores solitárias ou inflorescência em cimas dicasiais; cálice com sépalas desiguais, 1-1,5 ×0,2-0,7 cm, lanceoladas a ovadas, base atenuada, ápice obtuso, com rostro de coloração mais escura; corola alva com a face externa do tubo esverdeada, 11-14 
cm compr., hipocrateriforme, faixa mesopétala esverdeada; estames levemente desiguais, exsertos, pubescentes na base dos filetes; ovário glabro, estilete único, inteiro, estigmas 2 globosos. Fruto ovoide, 2,5-3 cm compr., apiculado; semente ca. $1-1,3 \times 0,7-0,8 \mathrm{~cm}$.

Material examinado: Guapimirim, Parque Nacional da Serra dos Órgãos, 13.VII.2009, fl., A.L.O. Moura 54 \& R.S. Nunes (RB); Rio de Janeiro, 03.VI.1988, fl. e fr. L.C. Giordano et al. 410 (RB); Petrópolis, Cascatinha, sem data, fl. O.C. Góes (RB 49777).

Material adicional examinado: BRASIL. RIO DE JANEIRO: Angra dos Reis, Ilha Grande, 6.III.2002, fl., C.C. Zysko, L.A. Ribas \& S. Scheider 246 (HB); Resende, 27.IV.1926, fl. F.C. Hoehne \& G. Gehrt (SP 17598).

Ipomoea alba ocorre em todo território brasileiro sendo frequentemente observada em áreas úmidas, às margens de cursos d’água. Neste estudo, a espécie foi coletada na Floresta Ombrófila Densa Montana do Parnaso a cerca de 753 m.s.m., em um forófito de $88 \mathrm{~cm}$ de CAP. Esta espécie é conhecida popularmente como "Damada-noite”, “Boa-noite” ou "Flor-da-noite”, devido as suas vistosas flores brancas e perfumadas, que se abrem ao entardecer e permanecem abertas durante toda noite até as primeiras horas da manhã. Além de seu valor ornamental também é citada como medicinal no Havaí, onde seu bulbo é consumido contra vômitos (Nagata 1971). Indivíduos férteis da espécie podem ser facilmente reconhecidos pela corola alva, infundibuliforme e o rostro de coloração mais escura nas sépalas. Além destes caracters, a presença de emergências escamiformes no caule e os estames exsertos são diagnósticos para distinguir I. alba das demais espécies do gênero Ipomoea analisadas no presente estudo.

7. Ipomoea aristolochiifolia G. Don., Gen. Hist. 4: 277. 1838.

Fig. 5a

Trepadeira herbácea, com tricomas simples. Lâmina simples 1,5-7,2 × 0,8-4,7 cm, pilosa a glabrescente na face adaxial, cordiforme, base cordada, subcordada a hastada, ápice agudo a acuminado. Flores solitárias, em cima ou em dicásio simples. Cálice com sépalas iguais, cartáceas, glabrescente na face externa, 5-7 × 2-3 $\mathrm{mm}$, lanceoladas, base atenuada, ápice apiculado; corola lilás a rósea, com fauce alvacente, 1,5-2 cm compr. campanulada; estames desiguais, inclusos, base dos filetes glabra; ovário piloso, estilete único, inteiro, estigma único, bilobado.
Fruto ovoide, $0,8-1 \mathrm{~cm}$ compr., apiculado; septo membranáceo; semente 3-4 × 2-3 mm, pilosa.

Material examinado: Petrópolis, Corrêas, III.1994, fl. e fr. O.C. Góes 167 (RB); Petrópolis, Maria Comprida, 1944, fl. e fr. O.C. Góes 358 (RB); Petrópolis, Cairú, VI.1943, fl. e fr. O.C. Góes 630 (RB).

Material adicional examinado: BRASIL. RIO GRANDE DO SUL: Porto Alegre, Ilha das Flores, 22.IV.1949, fl. S.J.B. Rambo 41170 (RB).

Ipomoea aristolochifolia é nativa da América tropical (Groth 1984), e ocorre como invasora de culturas em vários estados brasileiros. Neste estudo a espécie foi registrada apenas no Parnaso. Distingue-se das demais espécies do gênero Ipomoea com estigma bilobado por seu cálice com sépalas de dimensões iguais, a base dos filetes glabra, o ovário piloso e fruto ovoide.

8. Ipomoea batatas (L.) Lam., Tabl. Encycl. 1: 465. 1793.

Erva rastejante, com os ramos apicais volúveis. Caule pubescente a glabrescente, sem emergências escamiformes. Lâmina simples 3,5-9 $\times 2,8-8,5 \mathrm{~cm}$, pubescente sobre a nervura da face abaxial, cordiforme a deltoide, 3-7 lobada, base hastada, sagitada, cordada ou auriculada, ápice de agudo a acuminado ou obtuso, margem levemente ciliada. Inflorescência dicásio ou cimas. Cálice com sépalas desiguais, $0,7-1 \times 0,3-0,4 \mathrm{~cm}$, lanceoladas a ovadas, base atenuada a cuneada, ápice caudado a mucronado, margem ciliada; corola lilás, 3,5-4,5 cm compr., infundibuliforme; estames desiguais, inclusos, pubescentes na base dos filetes; ovário hirsuto, estilete único, inteiro, estigmas 2, globosos. Fruto globoso, pubescente, 6-8 mm compr.; semente 2-3 2 $2 \mathrm{~mm}$, glabra.

Material examinado: Petrópolis, 6.I.1948, fl., O.C. Góes (RB 49782).

Material adicional examinado: BRASIL. RIO DE JANEIRO: Angra dos Reis, Ilha Grande, 12.IV.2003, fl., C.C. Zysko 326 (HB).

Ipomoea batatas apresenta ampla distribuição em todo o Brasil, ocorrendo tanto em áreas de vegetação natural como em áreas antropizadas. É popularmente conhecida como "batata-doce" e largamente cultivada devido à importância alimentícia de suas raízes tuberosas. O hábito rastejante com ramos apicais volúveis e a presença de ovário hirsuto distinguem I. batatas das demais espécies do gênero Ipomoea, tratadas no presente trabalho, que possuem folhas simples, corola infundibuliforme, dois estigmas e estames inclusos. 
9. Ipomoea cairica (L.) Sweet., Hort. Brit. 1: 287. 1827. Figs. 3g,h; 5b

Trepadeira herbácea, glabra. Estrutura estipulácea palmatissecta na base do pecíolo; lâmina simples 1,8-4 × 2-5,2 cm, palmatissecta, 5-7 lobada, base sagitada, ápice agudo a mucronulado, venação basal. Flores em dicásio simples. Cálice com sépalas desiguais, 5-7 × 3-5 mm, ovadas a obovadas, estriadas na face interna, base atenuada a truncada, ápice redondo a atenuado, mucronulado; corola lilás, 3,8-5,7 cm compr., infundibuliforme; estames desiguais, inclusos pubescente na base dos filetes; ovário glabro, estilete único, bifurcado no ápice, estigmas 2, ovoides. Fruto globoso, 1-1,2 cm compr.; semente ca. 4-5 × 5-6 mm, pilosa.

Material examinado: Teresópolis, Parque Nacional da Serra dos Órgãos, 21.XI.2008, fl., A.L.O. Moura et al. 23 (RB); Petrópolis, Vale Bonsucesso, 5.IV.1968, fr., D. Sucre 2637 \& P.I.J. Braga 478 (RB); Petrópolis, 19.II.1937, fl., H. Monteiro 1546 (RBR); Itatiaia, Parque Nacional de Itatiaia, 22.IV.2009, fl. e fr., A.L.O. Moura 32 \& R.S. Nunes (RB); Magé, Parque Nacional da Serra dos Órgãos, Santo Aleixo, 11.VI.2009, fl., A.L.O. Moura 44 \& R. S. Nunes (RB).

Material adicional examinado: BRASIL. RIO DE JANEIRO: Sapucaia, 14.IX.2003, fr., G.V. Somner et al. 1120 (RBR); Arraial do Cabo, 20.10.1994, fl., $R$. Paixão et al. 302 (RB 309659; SP 388045); Angra dos Reis, Ilha Grande, 12.IV.2003, fl., C.C. Zysko 325 (HB);

Ipomoea cairica tem ampla distribuição geográfica e ocorre em formações de Floresta Estacional Decidual, Floresta Estacional Semidecidual, Floresta Ombrófila Densa/Aberta, Floresta Ombrófila Mista e Restinga. No Parnaso ocorre, a 230 m.s.m e a 444 m.s.m. nas formações Submontana e Montana, respectivamente, e no PNI, a cerca de 500 m.s.m na formação Montana. O CAP dos forófitos variou de 5 a $12 \mathrm{~cm}$, sendo o menor CAP registrado na Rebio Poço das Antas e o maior no Parnaso.

Popularmente conhecida como "corriola" ou "corda-de-viola", seu óleo essencial possui propriedades larvicidas contra larvas de Culex tritaeniorhynchus, Aedes aegytpi, Anopheles stephensi e Culex quinquefasciatus (Thomas et al. 2004). Uma das características mais marcantes de I. cairica, além de suas folhas palmatissectas, é a presença de estrutura estipulácea, da mesma forma das folhas, localizada na base dos pecíolos. $\mathrm{Na}$ literatura não são fornecidas informações sobre a origem desta estrutura, que é normalmente tratada como pseudo-estípula.
10. Ipomoea cynanchifolia Meisn, in Martius, Fl. Bras. 7: 274. 1869.

Fig. 3i-k

Trepadeira herbácea ou erva rastejante, pubescente a glabrescente, com ramos volúveis. Lâmina simples 1,5-3,5 × 0,7-1,5 cm, cordiforme, ocasionalmente 3 lobada, base cordada, subcordada, hastada ou sagitada, ápice agudo a acuminado, mucronulado, margem ciliada. Flores solitárias ou em dicásio simples. Cálice com sépalas desiguais, 3-4 × 2-3 mm, cartáceas, ovadas a obovadas, base redonda a obtusa, ápice obtuso a levemente retuso, ocasionalmente mucronado; corola 0,8-1,2 cm compr., lilás, campanulada; estames desiguais, inclusos, pubescentes na base do filete; estilete único, inteiro, estigmas 2, globosos. Fruto ovoide, 6-8 $\times$ 5-6 mm, cálice persistente; semente 3-4 × 2-3 $\mathrm{mm}$, glabra.

Material examinado: Silva Jardim, Reserva Biológica de Poço das Antas, 29.VII.2009, fl. e fr., A.L.O. Moura et al. 66 (RB).

Material adicional examinado: BRASIL. MINAS GERAIS: Ituiutaba, 20.IV.1944, fl. e fr., A. Macedo 331 (RB).

Ipomoea cynanchifolia foi registrada em áreas de campo antrópico da Rebio Poço das Antas, ocorrendo a 7 m.s.m. A espécie é afim de I. ramossisima, porém se diferencia desta, pelas sépalas obovadas com ápice obtuso a levemente retuso e pelo fruto ovoide.

11. Ipomoea daturiflora Meisn. Fl. Bras. (Martius) 7: 273. 1869.

Trepadeira herbácea, pubescente. Lâmina simples 5,2-12,5 × 4,7-11 cm, cordada, base cordada a subcordada, ápice agudo. Flores em cimas 1-3 floras. Cálice com sépalas desiguais, três externas maiores $2-2,7 \times 0,6-1 \mathrm{~cm}$, pubescentes na face externa e duas internas menores $1-1,2 \times$ $0,5-0,7 \mathrm{~cm}$, glabras, lanceoladas, base atenuada a cuneada, ápice cuspidado a mucronulado; corola lilás, 6,2-8 cm compr., infundibuliforme; estames desiguais, inclusos; ovário glabro, estiletes 2, inteiros, estigmas 2, globosos. Fruto globoso, 1-1,2 cm compr.; semente ca. 4-5 × 5-6 mm, pilosa, tricomas curtos revestindo toda a superfície da testa. Sementes pilosas, com tricomas curtos $(<1,5 \mathrm{~cm}$ compr.) revestindo toda a superfície da testa.

Material examinado: Petrópolis, Vale da Cachoeira, Araras. 2.III.1980, fl., V.F. Ferreira 1083 (RB); Petrópolis, 22.II.1937, fl., H. Monteiro 1601 (RBR). 
Material adicional examinado: BRASIL. RIO DE JANEIRO: Miguel Pereira, 25.III.1962, fl., G.F.J. Pabst 6891 (HB); Base da Serra da Piaba, Vertente S. 28.X.1971, fl., D. Sucre 7834 (RB); Nova Friburgo, Estrada Friburgo-Vargem Alta, 13.II.1984, fl., E.L. Costa 251 (RB); Estr. Olaria-São Lourenço, Vale São Lourenço, 29.III.1989, fl., E.L. Jacques 70 (RB).

Ipomoea daturiflora é endêmica da Floresta Atlântica (Simão-Bianchini et al. 2015), referida para áreas de capões e matas úmidas das Florestas Ombrófila Densa e Aberta. Neste estudo foi registrada em áreas do domínio do Parnaso.

Segundo Giulietti et al. (2009) I. daturiflora é uma espécie rara na flora fanerogâmica do Brasil e está incluída no anexo I da Lista oficial de Espécies ameaçadas de extinção do Ministério do Meio Ambiente, na categoria das espécies brasileiras com insuficiência de dados (Ministério do Meio Ambiente 2008). Apresenta afinidades com I. phyllomega, entretanto se distingue desta, principalmente, pelo indumento piloso da semente e por tricomas mais curtos $(<1,5 \mathrm{~cm}$ compr.).

12. Ipomoea grandifolia (Dammer) O’Donell, Arq. Mus. Paraense 9: 222. 1952.

Trepadeira herbácea, pubescente a glabrescente. Lâmina simples 2,8-7,5 × 1,7-6,2 $\mathrm{cm}$, cordiforme a 3 lobada, base cordada a subcordada, ápice agudo, margem ocasionalmente ciliada. Inflorescência em cima dicasial. Cálice com sépalas desiguais, glabras, frequentemente três externas maiores $0,8-1 \times 0,4-0,5 \mathrm{~cm}$, e duas internas menores 6-8 $\times 3-4 \mathrm{~mm}$, obovadas a lanceoladas, base atenuada a cuneada, ápice mucronado a longamente caudado; corola 1,7-2 cm compr., rosada ou purpurea, campanulada; estames desiguais, inclusos; ovário hirsuto com tricomas dourados, estilete único, inteiro, estigmas 2, globosos. Fruto globoso, 5-7 mm compr.; semente ca. 3-4 × 2-3 mm, glabra.

Material examinado: Petrópolis, sem data, fl., O.C. Góes (RB 49790).

Material adicional examinado: BRASIL. MINAS GERAIS: Paraíso, Fazenda Fortaleza, sem data, fl. e fr., A.C. Brade 17585 (RB).

Ipomoea grandifolia é considerada uma das plantas daninhas mais prejudiciais nas culturas anuais e perenes de verão das regiões sudeste e sul do país, sendo a planta mais frequente nas infestações de culturas de soja e milho (Bianco et al. 2007). Nas áreas de Floresta Atlântica é referida para as formações de Floresta Ombrófila, incluindo áreas de Restinga, além de Áreas Antrópicas.
No presente estudo foi registrada para a Floresta Ombrófila Densa Montana do Parnaso. Ipomoea grandifolia é afim de I. triloba, porém se diferencia pelo estigma duplo (vs único em I. triloba).

13. Ipomoea hederifolia L., Syst. Nat. (ed. 10) 925. 1759.

Fig. $5 \mathrm{c}$

Trepadeira herbácea, pubescente a glabrescente, com caule pubescente apenas nas axilas foliares. Lâmina simples 1,7-12 × 1,2-10,3 $\mathrm{cm}$, cordiforme a 3 lobada, base, cordada, subcordada ou hastada, ápice agudo, mucronado. Inflorescência em dicásio composto. Cálice com sépalas externas 3-6 mm, internas 2-3 mm, imbricadas, obovadas a lanceoladas, base atenuada à cuneada, ápice rostrado com apêndice subapical; corola avermelhada, 2,5-4 cm compr., hipocrateriforme; estames desiguais, exsertos; estilete e estigma únicos, globoso. Fruto globoso, 6-7 mm diam.; semente pubescente ca. $3-4 \times 4 \mathrm{~mm}$.

Material examinado: Itatiaia, 1936, fl. e fr., L. Laustiaki 153 (RB); Petrópolis, Correias, 25.V.1968, fl., D. Sucre 3104 (RB).

Material adicional examinado: BRASIL. RIO DE JANEIRO: Resende, fl. e fr., F.L. Hoehne \& G. Gehrt (SP 17597); Espírito Santo: Cachoeira de Itapemirim, VII.1950, fl. e fr., J. Nascimento (RB 70729).

Ipomoea hederifolia é conhecida popularmente como "corda-de-viola" sendo considerada uma espécie invasora de ampla distribuição principalmente, em ambientes perturbados ou áreas de cultivo. No presente estudo a espécie foi coletada na Floresta Ombrófila Densa Montana do PNI e dentre as demais espécies do gênero Ipomoea que apresentaram estigma único e globoso I. hederifolia pode ser diferenciada pela corola avermelhada, estames exsertos e sementes pubescentes.

14. Ipomoea indica (Burm. f.) Merr. Interpr. Herb. Amboin. 445. 1917 [1917].

Trepadeira herbácea, indumento de piloso a pubescente. Lâmina simples 3-10 × 2-12,7 cm, cordiforme, frequentemente 3 lobada, base cordada, subcordada ou hastada, ápice agudo, mucronado. Inflorescência em dicásio ou cima. Cálice com sépalas desiguais, imbricadas, $1,5-2,8 \times 0,2-0,3$ $\mathrm{cm}$, membranáceas, lanceoladas, indumento adpresso piloso a pubescente, esparso, base atenuada a cuneada, ápice caudado; corola 5,5-7,5 cm compr., lilás a purpúrea, infundibuliforme; estames desiguais, inclusos; ovário glabro, estilete único, inteiro, estigma único, globoso. 
Fruto globoso, 5-7 mm diâm., estilete persistente; semente ca. 2-3 × $3 \mathrm{~mm}$, glabra.

Material examinado: Petrópolis, Corrêas, X.1943, fl., O.C. Góes 662 (RB); Petrópolis, Quitandinha, 1946, fl., O.C. Góes 32 (RB); Guapimirim, Parque Nacional da Serra dos Órgãos, 13.VII.2009, fl., A.L.O. Moura 53 \& R. S. Nunes (RB); Itaiaia, Parque Nacional de Itatiaia, 21.IV.2009, fl., A.L.O. Moura et al. 29 (RB); Itatiaia, Lago Azul, próximo da estrada, 14.II.1995, fl. e fr. J.M.A Braga 1984 (RB); Itatiaia, Parque Nacional de Itatiaia, X.1991, fl., R. Simão-Bianchini 5 (SP).

Material adicional examinado: BRASIL. RIO DE JANEIRO: Itatiaia, 17.XI.1994, fl., R. Simão-Bianchini 578 (SP); Vassouras, III.1940, fl., H. Monteiro 2302 (RBR).

Ipomoea indica é amplamente distribuída em todo o Brasil e apesar de ocorrer como planta invasora de algumas culturas é muito apreciada para uso ornamental devido à intensa coloração de suas flores. Ocorre desde áreas de baixadas até as de altitudes mais elevadas em formações de Floresta Ombrófila Densa, Ombrófila Aberta, Ombrófila Mista e na Floresta Estacional Semidecidual. Neste estudo a espécie foi encontrada na floresta Montana do PNI, entre 650 e 812 m.s.m., em forófitos variando de 2 a $15 \mathrm{~cm}$ de CAP e do Parnaso a 676 m.s.m. em um forófito de $23 \mathrm{~cm}$ de CAP.

Ipomoea indica e $I$. purpurea, pertencem ao complexo Ipomoea nil (Austin 1986) e são consideradas espécies afins. Segundo os conceitos de Austin (1980) e Hsu et al. (2006) podem ser diferenciadas pelo tipo de indumento das sépalas, adpresso piloso ou seríceo na face dorsal em $I$. indica e híspido com tricomas adensados na base dorsal das sépalas, em I. purpurea. No material estudado as características observadas corroboram os conceitos dos autores supracitados. Ipomoea indica possui indumento mais esparso, variando de adpresso piloso a pubescente, tanto nas sépalas como nos ramos em geral e sépalas estreitas e alongadas, enquanto que em $I$. purpurea o indumento é híspido, presente por toda a planta, e os tricomas são adensados na porção basal da face externa das sépalas.

15. Ipomoea indivisa (Vell.) Hallier f. Meded. Rijks-Herb. 46: 20. 1922.

Trepadeira herbácea, pubescente a glabrescente com caule pubescente apenas nas axilas foliares. Lâmina simples 2,3-7 × 1,8-3,5 cm, cordiforme, base cordada, subcordada ou sagitada, ápice agudo, mucronado. Inflorescência em dicásio. Cálice com sépalas desiguais, 3-5 × 2-3 mm, com pontuações na face interna, obovadas a ovadas, base atenuada a cuneada, ápice obtuso, com rostro subapical, ca. 2 cm; corola 2-2,5 cm compr., avermelhada, hipocrateriforme; estames desiguais, pubescentes na base dos filetes, inclusos; ovário glabro, estilete, único, inteiro, estigma único, bilobado. Fruto globoso, 5-8 mm diam. glabro; semente ca. 3-4 × $3 \mathrm{~mm}$, densamente pilosa.

Material examinado: Petrópolis, Itamarati, III.1944, fl. e fr., O.C. Góes 260 (RB); Jacó, 29.IV.2008, fl., M. Nadruz 2196 (RB).

Material adicional examinado: BRASIL. SÃO PAULO: Itapira, 13.V.1927, fr., F.C. Hoehne (RB 416333).

Ipomoea indivisa ocorre em áreas de Floresta Atlântica sendo referida para formações de Floresta Ombrófila, incluindo a tipologia Floresta Ombrófila Mista e áreas de Restinga, além de ocorrer em ambientes antropizados. Neste estudo a espécie foi registrada em áreas de Floresta Ombrófila Densa Montana do Parnaso. Segundo Groth (2001) I. indivisa é muito próxima de $I$. coccinea L., espécie que entretanto, não ocorre no Brasil (Simão-Bianchini \& Ferreira 2015). Ambas diferenciam-se por características da semente ocorrendo para I.coccinea indumento tomentoso, uniforme e com tricomas esparsos curtos translúcidos e em I. indivisa indumento tomentoso com tricomas longos, cobre-translúcidos nas margens e áreas dorsal longitudinais e tricoma irregular cobre ou translúcido amarelado na face e quilha. Entre as espécies estudadas no presente trabalho I.indivisa apresenta semelhança com I.tiliaceae, distinguindo-se desta pela presença de rostro nas sépalas e pelo fruto glabro (vs. sépalas sem rostro e fruto com tricomas em I. tiliaceae).

16. Ipomoea phyllomega (Vell.) House, Ann. New York Acad. Sci. 18(6): 246. $1908 . \quad$ Fig. 31

Trepadeira lenhosa. Caule glabro, frequentemente estriado. Lâmina simples 4-17 $\times$ 4,2-16 cm, pubescente a glabrescente na face abaxial, principalmente sobre a nervura e glabrescente na face adaxial, cordiforme, base cordada, subcordada ou auriculada, ápice agudo. Inflorescência em cima multiflora. Cálice com sépalas desiguais, duas externas maiores 1-1,3 $\times 1-1,5 \mathrm{~cm}$ e três internas menores $0,8-1 \times$ 0,7-0,8, membranáceas, orbiculares a obovadas, base redonda a obtusa, ápice redondo a obtuso, mucronulado, margem ocasionalmente ciliada; corola 4,5-5,2 cm compr., lilás, infundibuliforme; 
estames desiguais, inclusos, pubescentes a glabrescentes na base do filete; ovário glabro, estilete único, inteiro, estigmas 2 globosos. Fruto globoso, 1,2-1,5 × 1-1,2 cm, cálice acrescente; sementes ca. 6-7 $\times$ 4-5 mm, hisurtas na face dorsal-apical, com tricomas longos (ca. 1,5 cm compr.), dourados e frouxamente inseridos na porção dorso-apical da testa.

Material examinado: Silva Jardim, Rebio Poço das Antas, 29.VII.2009, fr., A.L.O. Moura 65, G.V. Somner \& R.S. Nunes (RB); Silva Jardim, Rebio Poço das Antas, 7.II.1995, fl. e fr., S.V.A. Pessoa 758 (RB); Guapimirim, Parque Nacional da Serra dos Órgãos, 12.VII.2009, fr., A L.O. Moura 51 \& R. S. Nunes (RB).

Material adicional examinado: BRASIL. RIO DE JANEIRO: Paraty, ponta da Trindade, 13.IV.1978, fl. e fr., G. Martinelli 4201 (RB); Casimiro de Abreu, Morro São João, 3.II.1970, fl. e fr., S.P.S. (RB 146315); Magé, estrada de Magé, 11.XII.1947, fl. e fr., A.P. Duarte, 1012 (RB); Friburgo, 3.III.1965, fl., E. Pereira 9894 (HB); Macaé, 11.I.1985, fl., A. Gentry et al. 49422 (RBR).

Ipomoea phyllomega apresenta ampla distribuição sendo registrada em todas as regiões do Brasil desde áreas alagadiças de restinga até altitudes elevadas nas formações de Floresta Ombrófila Densa e Aberta.

Na região Serrana de Nova Friburgo, RJ, foi registrada a ca. 1500 m.s.m. No presente estudo a espécie foi registrada na formação Submontana do Parnaso a 112 m.s.m em um forófito de $28 \mathrm{~cm}$ de CAP e na Rebio Poço das Antas em formações de capoeiras e formações pioneiras nas áreas de influência fluvial.

Ipomoea phyllomega é conhecida popularmente como “cipó-batata”; quando estéril, pode ser reconhecida pelas folhas discolores com face abaxial vinácea. A cápsula, quando madura, aparenta possuir tricomas em sua superfície, entretanto tais tricomas se localizam na testa da semente e estão frouxamente presos a esta, na região dorso-apical. O indumento hirsuto da semente e os tricomas longos (ca. 1,5 cm compr.) são caracteres que a distinguem da espécie afim I. daturiflora.

17. Ipomoea purpurea (L.) Roth, Bot. Abh. Beobacht. 27. 1787.

Trepadeira herbácea. Caule piloso a pubescente. Lâmina simples 4-10,2 × 3,8-9,2 $\mathrm{cm}$, pubescente, cordiforme a três lobada, base cordada, subcordada a hastada, ápice agudo a acuminado, margem ciliada. Flores solitárias ou em dicásio simples. Cálice com sépalas desiguais, imbricadas, oblongo-lanceoladas 1,2-1,7 × 0,3-0,4 cm, cartáceas, base atenuada, ápice caudado, indumento híspido adensado na porção basal da face externa; corola 4,5-5,5 cm compr., lilás a purpúrea, interior do tubo branco, faixa mesopétala mais clara na face externa da corola, infundibuliforme; estames desiguais, inclusos, pubescentes na base do filete; ovário glabro, estilete único, inteiro, estigma único, globoso. Fruto globoso, 0,6-0,9 × 0,8-1,2 cm; semente 4-5 × 2-3 mm, glabra.

Material examinado: Petrópolis, VI.1943, fl. e fr., O.C. Góes (RB 49784); 10.V.1989, fl., L. Mautone 106 (RB); Itatiaia, Parque Nacional de Itatiaia, 21.IV.2008, fl., A.L.O. Moura 17 (RB).

Material adicional examinado: BRASIL. MINAS GERAIS: Caxambú, 8.VI.1957, fl. e fr., G.F.J. Pabst 4037 (HB); Sete Lagoas, 5.IV.1934, fl., I. Barçante 372 (RBR); São Paulo: São Paulo, 29.III.1955, fl., W. Hoehne (RB 344883).

Ipomoea purpurea é nativa da Américas (Austin 1975) e nas áreas de Floresta Atlântica ocorre nas formações de Floresta Ombrófila Aberta, Mista e na Floresta Estacional Semidecidual, sendo frequentemente avistada em áreas de maior altitude. A espécie é afim de I. indica e os principais caracteres diagnósticos para separação entre ambas foram mencionados nos comentários de I. indica.

18. Ipomoea ramosissima (Poir.) Choisy, in DC. 9: 377. 1845.

Trepadeira herbácea, pubescente a glabrescente. Lâmina simples 1,7-5,5 × 1,8$4,5 \mathrm{~cm}$, cordiforme a 3 lobada, base cordada a subcordada, ápice agudo a acuminado, mucronulado, margem ciliada. Inflorescência em dicásio simples. Cálice com sépalas desiguais, 4-5 × 3-4 mm, cartáceas, oblongas a ovadas, base arredondada a obtusa, ápice mucronado a aristado, com tricomas mais adensados na porção basal da sépala; corola 1,7-3,5 cm compr., lilás claro, interior do tubo mais escuro, campanulada; estames desiguais, inclusos; ovário glabro, estilete único, inteiro, estigmas 2 globosos. Fruto globoso, 7-8 × 6-7 cm; semente 3-4 × 2-3 cm, glabra.

Material examinado: Teresópolis, Parque Nacional da Serra dos Órgãos, 21.XI.2008, fl., A.L.O. Moura et al. 24 (RB); Itatiaia, Parque Nacional de Itatiaia, 22.IV.2009, fl., A.L.O. Moura et al. 35 (RB); Itatiaia, Parque Nacional de Itatiaia, 21.IV.2009, fl. e fr., A.L.O. Moura et al. 30 (RB); Magé, Parque Nacional da Serra dos Órgãos, Distrito de Santo Aleixo, 26.IX.2007, fl., M. Nadruz 2050 (RB); Magé, Parque Nacional da Serra 
dos Órgãos, Distrito de Santo Aleixo, 11.VI.2009, fl. e fr., A.L.O. Moura \& R.S. Nunes 42 (RB).

Material adicional examinado: BRASIL. RIO DE JANEIRO: Porciúncula, 26.VII.1966, fl. e fr., C. Martins \& A. Sobreira (HB 39686); Morro Azul, 14.V.1944, fl. e fr., F.S. Vianna 468 (HB); Itaguaí, 1.XII.1988, fl., A.A. Gomes 22 (RBR); Barra do Piraí, 13.IV.1956, fl., F.C. Hoehne \& A. Gehrt. (SP 17317).

Ipomoea ramosissima tem ampla distribuição no Brasil, sendo referida para diferentes formações florestais e também para áreas antrópicas. A espécie foi coletada nas florestas Submontana e Montana do Parnaso entre 230 e 614 m.s.m., em forófitos variando de 6 a $10 \mathrm{~cm}$ de CAP e no PNI na floresta ontana a ca. 700 m.s.m. em forófitos de 5 a 7 cm de CAP.

Ipomoea ramosissima possui grande semelhança morfológica com I. cynanchifolia, diferenciando-se desta pelo ápice mucronado a aristado das sépalas e o fruto globoso.

19. Ipomoea regnellii Meisn., in Martius, Fl. bras. 7: 266.1869.

Fig. 5d,e,f

Trepadeira lenhosa. Caule hisurto com tricomas dourados. Lâmina simples 11-13,5 × 9-11 cm, pubescente a glabrescente nas folhas maduras e velutinas nas folhas jovens, cordiforme, base cordada, ápice acuminado, mucronado. Inflorescência em dicásio simples. Cálice com sépalas desiguais, 0,8-1 × 0,3-0,4 cm, velutinas, cartáceas, ovadas a lanceoladas, base cuneada a obtusa, ápice obtuso a retuso ou agudo, apiculado; corola 5,5-6,5 cm compr., rósea infundibuliforme; estames desiguais, inclusos, pubescentes na base do filete; ovário glabro, estilete único, inteiro, estigmas 2, globosos. Cápsula 1,5-2 × 0,8-1,2 cm, ovoide; sementes 4-5 × 2-3 mm, pubescentes. Material examinado: Itatiaia, Parque Nacional de Itatiaia, estrada principal, 30.V.2009, fl., A.L.O. Moura 41 \& R.S. Nunes (RB).

Material adicional examinado: BRASIL. MINAS GERAIS: Capitólio, 24.VII.1993, fl., R. Simão-Bianchini \& S. Bianchini 409(SP); São Paulo: São José do Barreiro, 04.V.1997, fl. e fr., R. Simão-Bianchini \& S. Bianchini 1169 (SP).

Ipomoea regnellii foi coletada durante as campanhas de campo do presente estudo na floresta Montana do PNI a 652 m.s.m., ascendendo em um forófito de $10 \mathrm{~cm}$ de CAP, sendo este o primeiro registro da espécie para o estado do Rio de Janeiro. A inflorescência em dicásio e o fruto ovoide distinguem $I$. regnellii das demais espécies volúveis, de folhas simples, corola infundibuliforme, ovário glabro e com 2 estígmas.
20. Ipomoea saopaulista O’Donell Lilloa 26. 392 (1953).

Trepadeira lenhosa, tomentosa a glabrescente. Lâmina simples 3,5-10,5 × 3,8-12,2 cm, com indumento densamente tomentoso na face abaxial, cordiforme, base cordada a subcordada, ápice agudo a acuminado, mucronulado. Inflorescência tirso. Cálice com sépalas desiguais, 5-8 × 3-4 mm, cartáceas, ovadas, base redonda a obtusa, ápice arredondado; corola 2,3-2,5 cm compr., alva, campanulada; estames desiguais, inclusos, base dos filetes pubescentes com tricomas vilosos; ovário glabro, estilete único, inteiro, estigma único, bilobado. Fruto globoso, 0,8-1,2 × 1-1,3 cm, cálice acrescente; sementes 4-5 × 3-4 mm, densamente pilosas na face dorsal, com tricomas dourados, ca. $7 \mathrm{~mm}$ compr.

Material examinado: Itatiaia, proximidades da entrada principal do Parque, 13.III.1996, fl. e fr., J.M.A. Braga 3270 (RB); Petrópolis, 23.III.1968, fl., D. Sucre 2535 (RB); Petrópolis, 12.IV.1968, fl. e fr., D. Sucre 2703 (RB); Petrópolis, 3.III.1963, fl., G.F.J. Pabst 7326 (HB); Vale das Videiras, 14.III.1976, fl. e fr., G. Martinelli 801 (RB 193184).

Material adicional examinado: BRASIL. SÃO PAULO: Campinas, 30.III.1977, fl. e fr., J. Semir (RB 252575).

Ipomoea saopaulista ocorre em diferentes biomas do Brasil e em áreas de Floresta Atlântica a espécie é referida para formações de Floresta Ombrófila, incluindo áreas de Floresta Ombrófila Mista, e Floresta Estacional Semidecidual. No presente estudo a espécie foi registrada nos domínios do PNI e do Parnaso. Uma das características mais marcantes de I. saopaulista é o indumento densamente tomentoso na face abaxial das lâminas foliares.

21. Ipomoea syringifolia Meisn., in Martius. Fl. bras. 7: 270. 1869.

Fig. 3m

Trepadeira herbácea, freqüentemente glabra. Lâmina simples 2,5-6 × 2,3-4 cm, cordiforme, base cordada a subcordada, ápice agudo a acuminado, mucronulado, margem inteira ou levemente ondulada. Inflorescência em cima dicasial. Cálice com sépalas desiguais, 0,7-1 × 0,2-0,5 cm, membranáceas, ovadas a elípticas, base obtusa a atenuada, ápice redondo a abruptamente agudo; corola 2,7-5 cm compr., alva ou creme esverdeada, fauce arroxeada, campanulada; estames desiguais, inclusos, pubescentes na base do filete; ovário glabro, estilete único, estigmas 2, globosos. Fruto globoso, 1-1,3 × 0,8-1 cm; sementes 4-5 × 2-3 


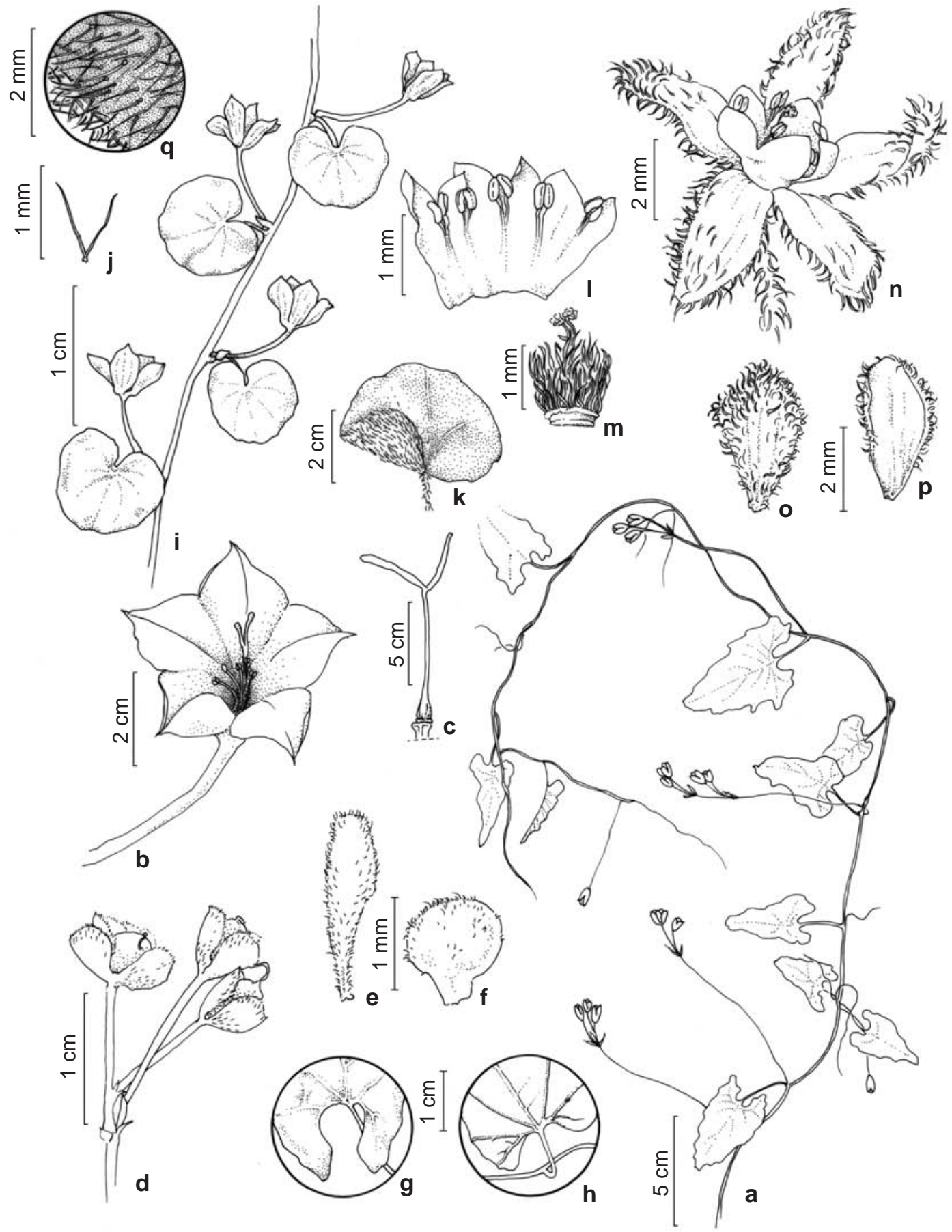

Figura 4 - a-h. Convolvulus crenatifolius Ruiz \& Pav. a. ramo florífero; b. flor; c. estigma; d. infrutescência; e. sépala externa; f. sépala interna; g. base da folha auriculada; h. base da folha hastada. i-k. Dichondra micrantha Urb. - i. ramo florífero; j. tricoma bífido; k. folha. 1-q. Dichondra sericea Sw. 1. flor aberta; m. ovário hirsuto; n. flor; o. sépala face externa; p. sépala face interna; q. detalhe do indumento piloso no caule. (a-h. Constatino 82; i-k. Góes 344; 1-q. Brade 15586).

Figure 4 - a-h. Convolvulus crenatifolius Ruiz \& Pav. a. floriferous stem; b. flower; c. stigma; d. infructescence; e. external sepal; f. internal sepal; g. base of the ear-shaped leaf; h. base of the spear-shaped leaf. i-k. Dichondra micrantha Urb. - i. flowering branch; j. bifid trichome; k. leaf. 1-q. Dichondra sericea Sw. 1. open flower; m. hisurte ovary; n. flower; o. outside face of the sepal; p. inside face of the sepal; q. detail of the hair covering on the stem. (a-h. Constatino 82; i-k. Góes 344; 1-q. Brade 15586). 

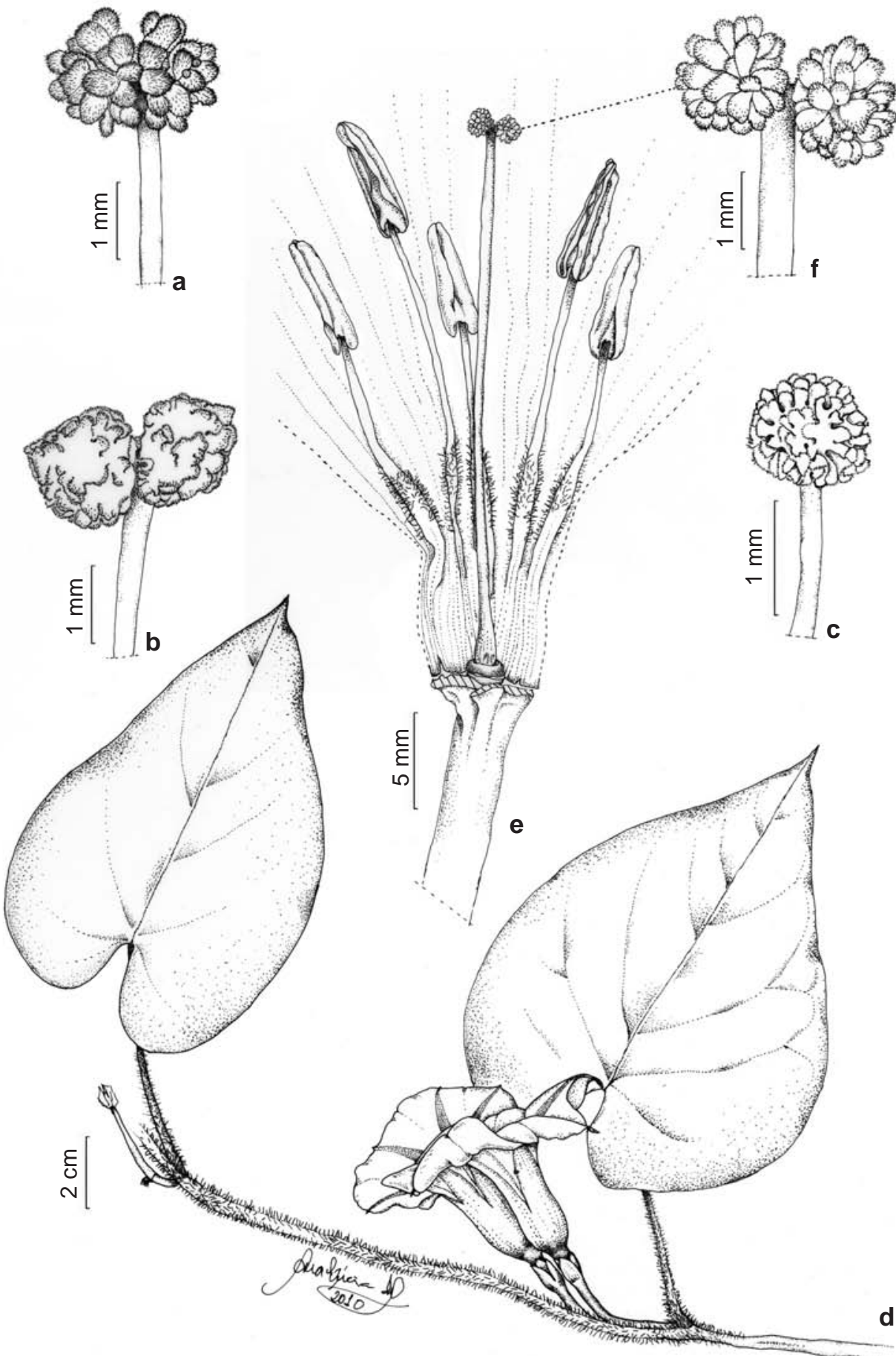

Figura 5 - a. Ipomoea aristolochifolia G. Don. - estigma único bilobado; b. Ipomoea cairica (L.) Sweet. - 2 estigmas ovoides; c. Ipomoea hederifolia L. - estigma único globoso. d,e,f. Ipomoea regnelli Meisn. - d. ramo florífero; e. corte longitudinal da flor; f. 2 estigmas globosos. (a. Góes 167; b. Moura \& Nunes 32; c. Laustiaki 153; d,e,f. Moura \& Nunes 41).

Figure 5 - a. Ipomoea aristolochifolia G. Don. - only bilobate stigma. b. Ipomoea cairica (L.) Sweet. - 2 oval stigmas. c. Ipomoea hederifolia L. - only unilobate stigma. d,e,f. Ipomoea regnelli Meisn. - d. flowering branch; e. longitudinal slice of the flower; f. 2 globe-shaped stigmas. (a. Góes 167; b. Moura \& Nunes 32; c. Laustiaki 153; d, e, f. Moura \& Nunes 41). 
mm, com a porção média apical da margem recoberta por tricomas longos (ca. 1 cm compr,) e dourados.

Material examinado: Petrópolis, Maria Comprida, III.1944, fl., O.C. Góes \& E.D. Constatino (RB 49791).

Material adicional examinado: BRASIL. RIO DE JANEIRO: Niterói, Itaipuaçú, 9.IX.1982, fl., $R$. Andreata 538 (RB); Rio de Janeiro, Jacarepaguá, 11.III.1959, fl. e fr., A.P. Duarte 4629 (RB).

Ipomoea syringifolia ocorre nos domínios fitogeográficos do Cerrado e da Floresta Atlântica, em formações de Floresta Ombrófila. No presente estudo a espécie foi registrada na Floresta Ombrófila Densa Montana do Parnaso. A presença de tricomas dourados na porção médio apical das sementes distingue I. syringifolia das demais espécies de folhas simples, inflorescência em cimas, corola campanulada e ovário com dois estigmas.

\section{Ipomoea tiliacea (Willd.) Choisy, in D. C.,} Prodr. 9: 375. 1845.

Trepadeira herbácea, pubescentes ou glabrescentes. Lâmina simples 4-7,3 × 1,5-7 $\mathrm{cm}$, pubescente, cordada, sagitada ou hastada, base cordada, subcordada, sagitada ou hastada, ápice agudo a acuminado, mucronulado, margem ciliada. Inflorescência em dicásio simples. Cálice com sépalas desiguais, 1-1,2 $\times$ 0,3-0,4 cm, membranáceas, ovadas, elípticas ou lanceoladas, base obtusa a atenuada, ápice obtuso a abruptamente agudo, apiculado; corola 4-5,5 cm compr., lilás a rósea, infundibuliforme; estames desiguais, inclusos, pubescentes na base do filete; ovário glabro, estilete e estigma únicos, bilobado. Fruto globoso, $0,7-0,8 \times 0,8-1 \mathrm{~cm}$, com tricomas esparsos na face externa; semente 4-5 × 2-3 mm.

Material examinado: Silva Jardim, Margens do Rio São João, 30.XI.1992, fl. e fr., M. Peron 959 (RB; SP 405754); área aberta na estrada da barragem, lado esquerdo sentido barragem, 2.IV.2009, fl., A.L.O. Moura \& G.V. Somner 26 (RB).

Material adicional examinado: BRASIL. RIO DE JANEIRO: Maricá, III.1934, fl., H. Monteiro 910 (RBR); Parati, Trindade, 14.III.1989, fl., L.C. Giordano et al. 583 (RB).

Ipomoea tiliaceae é referida para áreas de Floresta Atlântica principalmente em formações de Restinga. Foi coletada na Rebio Poço das Antas em um trecho de Capoeira Aluvial a 12 m.s.m., ascendendo em um forófito de $5 \mathrm{~cm}$ de CAP. A afinidade e caracteres diagnósticos de
I.tiliaceae com I. indivisa podem ser consultados nos comentários de I.indivisa.

23. Ipomoea triloba L. Sp. Pl. 1: 161. 1753.

Trepadeira herbácea, pubescente a glabrescente. Lâmina simples 1,9-5,5 × 2-4,3 $\mathrm{cm}$, cordada ou hastada, sagitada a 3-lobada, base cordada, subcordada, hastada ou sagitada, ápice agudo a acuminado, mucronulado, margem ciliada. Inflorescência em dicásio simples ou composto. Cálice com sépalas desiguais, imbricadas, 0,7-1,2 ×0,2-0,3 cm, membranáceas, ovadas a lanceoladas, base atenuada a cuneada, ápice acuminado, agudo a abruptamente agudo, ocasionalmente mucronado; corola 1,5-2,3 cm compr., rósea, lilás ou purpurea, campanulada; estames desiguais, inclusos; ovário hirsuto, estilete e estigma únicos globoso. Fruto globoso, 5-7 × 5-6 mm; semente 3-4 × 2-3 mm, glabra. Material examinado: Silva Jardim, Rebio Poço das Antas, 5.VII.1995, fl. e fr., S.V.A. Pessoa 799 (RB).

Material adicional examinado: BRASIL. RIO DE JANEIRO: Campos, 29.X.1980, fl., I.A.A. 32 (RBR), São Paulo: Pinhal, 13.11.1947, fl. e fr., E. Kühn \& M. Kuhlmann 1512 (SP).

Ipomoea triloba é uma espécie naturalizada e ocorre em diferentes domínios fitogeográficos do Brasil, sendo frequentemente associada a vegetação antropizada. Neste estudo a espécie foi coletada na Rebio Poço das Antas, em um trecho de Capoeira Aluvial. A corola campanulada e o ovário hirsuto são alguns dos caracteres que tornam I. triloba espécie afim de I. grandifolia (para afinidades e caracteres diagnósticos nos comentários desta espécie). Entretanto, estes mesmos atributos constituem os principais caracteres diagnósticos para separar I. triloba das demais espécies do gênero com estigma único.

Jacquemontia Choisy Mem. Soc. Phys. Genève 6: 476.1833.

Figs. 3n, o; 6

Trepadeiras herbáceas ou lenhosas. Indumento variado, com tricoma simples na base do filete e estrelado, nas demais estruturas que apresentam indumento. Folha simples, margem inteira ou raramente repandida ( $\mathrm{J}$. densiflora e $J$. blanchetti), venação bronquidódroma. Cálice com sépalas de tamanho igual ou desigual, imbricadas. Corola campanulada ou rotácea, glabra; estames desiguais, inclusos ou exsertos; ovário súpero, glabro, estiletes único, estigmas dois, ovais-planos, divergentes, papilosos. Fruto cápsula septifraga, glabra, ovoide ou globosa, 
8-valvar, sementes 4, com superfície escabrosa e duas alas estreitas laterais.

Jacquemontia é um dos gêneros de Convolvulaceae com maior número de espécies, aproximadamente 120 (Simão-Bianchini 1999; Pastore 2014), e dentre estas 67 ocorrem no Brasil, sendo que 44 são endêmicas (Simão-Bianchini et al. 2015). Conforme assinalado por Pastore (2014) as sépalas são de grande valor taxonômico para as espécies de Jacquemontia e no presente estudo as peculiaridades desta estrutura foram caracteres diagnósticos para as espécies deste gênero, com exceção a J. densiflora que se diferencia das demais espécies do grupo por apresentar inflorescência em cimas densas, compactas.

\section{Jacquemontia blanchetti Moric., Pl. Nov. Amer.} 41, t. 27. 1838.

Fig. 6a, b

Trepadeira herbácea, pubescente a glabrescente. Lâmina 3-8 × 2-6 cm, cordada a deltoide, base cordada, subcordada ou truncada, ápice agudo a acuminado, mucronado, margem inteira a levemente repandida. Inflorescência cima multiflora laxa. Cálice com sépalas desiguais, 4-5 $\times 2-3 \mathrm{~mm}$ membranáceas, lanceoladas a obovadas, base atenuada, ápice redondo a obtuso, apiculado, margem esverdeada, ocasionalmente ciliada, glabra; corola 1,8-2 cm compr., lilás a azulada. Cápsula ovoide, 3-4 × 3-4 mm, semente 2-3 × $2 \mathrm{~mm}$.

Material examinado: Itatiaia, Parque Nacional de Itatiaia, 30.V.2009, fl., A.L.O. Moura 40 \& R.S. Nunes (RB).

Material adicional examinado: BRASIL. MINAS GERAIS: Botumirim, Serra da Canastra, 21.VII.2004, fl. e fr., R.C. Forzza 3803 (RB).

Jacquemontia blanchetti ocorre em formações de Floresta Ombrófila Densa e Aberta e na Floresta Estacional Semidecidual. No Estado de Minas Gerais esta espécie foi coletada em matas perturbadas, com elementos de Cerrado, a 1109 m.s.m. Neste estudo a espécie foi coletada na Floresta Ombrófila Densa Montana do PNI a 657 m.s.m., sobre forófito de 2 cm de CAP.

Jacquemontia blanchetti possui afinidades com J. martii, entretanto pode ser diferenciada pelo ápice das sépalas redondo a obtuso (vs ápice agudo a acuminado em $J$. martii).

25. Jacquemontia densiflora (Meisn.) Hallier f. Bot. Jahrb. Syst. 16: 543. 1893.

Figs. 3n, o; 6c-h

Trepadeira herbácea com indumento velutino a pubescente presente no caule, folha e face externa da sépala. Lâmina 3,5-7,5 × 1,7-4 cm, cordiforme, lanceolada ou elíptica, base cordada, subcordada ou arredondada, ápice agudo a acuminado, freqüentemente apiculado, margem inteira a repandida. Inflorescência em cima densa, compacta. Cálice com sépalas desiguais, cartáceas, ovadas a obovadas, base arredondada a obtusa, ápice acuminado, 3-4×2-3 mm; corola 1,2-1,5 cm compr., lilás a azulada, faixa mesopétala alva na face externa da corola. Cápsula globosa, 5-7 × 4-5 mm; semente 2-3 × 1-2 mm.

Material examinado: Itatiaia, Parque Nacional de Itatiaia, Final da picada Barbosa Rodrigues, 22.IV.2009, fl., A.L.O. Moura 37 \& G.V. Somner (RB); Petrópolis. Estrada do Contorno, 27.I.1968, fl. e fr., D. Sucre 2272 (RB); Itatiaia, 27.II.1936, fl., A.C. Brade 15131 (RB).

Material adicional examinado: BRASIL. RIO DE JANEIRO: Itaguaí, Ilha da Madeira, 21.VII.1993, fl., S.A. Rego 1279, L. Gustavo \& N.H. Aquino (RBR); São Paulo: Cotia, IV.1941, fl. e fr., D. Constantino 81 (RB).

Jacquemontia densiflora é conhecida popularmente como "jitirana” e em áreas de Floresta Atlântica ocorre em formações de Floresta Ombrófila Densa e Floresta Ombrófila Aberta. Neste estudo a espécie foi coletada na Floresta Ombrófila Densa Montana do PNI a 665 m.s.m., ascendendo em um forófito de $15 \mathrm{~cm}$ de CAP.

Jacquemontia densiflora distingue-se das demais espécies deste gênero, abordadas no presente trabalho, pela inflorescência em cimas densas e compactas, ao contrário das demais que apresentam cimas laxas.

\section{Jacquemontia holosericea (Weinm.) O'Donell,} Lilloa 26: 357. 1953.

Fig. $6 \mathrm{i}$

Trepadeira lenhosa com indumento tomentoso a glabrescente no caule e na lâmina foliar. Lâmina 3,5-5,5 × 2,3-4,5 cm, cordiforme, ovada ou oblonga, base cordada, subcordada ou truncada, ápice obtuso, arredondado ou acuminado, mucronado, indumento mais adensado na face abaxial. Inflorescência cima laxa. Cálice com sépalas desiguais, cartáceas, pubescentes a glabrescentes na face externa, ovadas a obovadas, base arredondada a obtusa, ápice arredondado, obtuso a retuso, esverdeado, margem ciliada, uma das sépalas externas frequentemente menor que as demais, $4-5 \times 3-4 \mathrm{~mm}$, e as maiores 0,8-1 × 0,5-0,7 cm; corola 2-2,5 cm compr., lilás a azulada. Cápsula globosa 5-7 × 6-8 mm; semente $3-4 \times 1-2 \mathrm{~mm}$.

Material examinado: Silva Jardim, Reserva Biológica de Poço das Antas, 17.VIII.1995, fl. e fr., J. M.A. Braga et al. 2714 (RBR); Reserva Biológica de Poço das Antas, caminho para o Rio São João, Km 8, 23.II.1994, fl. e fr., A. Piratininga 33 (RB); Estrada para Juturnaiba, 
17.VIII.1995, fl. e fr., J.M.A. Braga 2714 (RB); Reserva Biológica de Poço das Antas, Estrada para barragem, km 8, 3.IV.2009, fl., A.L.O. Moura et al. 28 (RB).

Material adicional examinado: BRASIL. RIO DE JANEIRO: Rio de Janeiro, Restinga de Jacarepaguá, 15.V.1969, fl., D. Sucre 5007 (RB).

Jacquemontia holosericea é endêmica da Floresta Atlântica, sendo frequentemente observada em ambientes de restinga. Além de ocorrer em áreas de Floresta Ombrófila Densa também há registros da espécie em formações de Floresta Ombrófila Aberta. Neste estudo a espécie foi coletada na Rebio Poço das Antas em área de Capoeira Submontana a 17 m.s.m., ascendo em um forófito de $8 \mathrm{~cm}$ de CAP.

Jacquemontia holosericea, conhecida popularmente como “folha de Araruama”, é semelhante a J. velutina podendo ser distinguida principalmente pelas sépalas de tamanhos marcantemente distintos e pelo ápice da sépala que varia de arredondado a aretuso (vs sépalas levemente desiguais com ápice de agudo a apiculado, em J.velutina).

\section{Jacquemontia martii Choisy Prodr. (DC.) 9: 398.} 1845 [1 Jan 1845].

Fig. 6j

Trepadeira herbácea, pubescente a glabrescente. Lâmina 2-7 × 1,5-6,5 cm, cordiforme a ovada, base cordada a subcordada, ápice acuminado a apiculado. Inflorescência cima multiflora laxa. Cálice com sépalas iguais, 4-5 × 2 mm membranáceas, lanceoladas, base redonda, ápice agudo a acuminado, esverdeado, margem não ciliada, glabra; corola 1,7-2 cm compr., azulada. Cápsula ovoide, 6-8 × 5-6 mm; semente 3-4 $\times 1-2 \mathrm{~mm}$.

Material examinado: Petrópolis, Bairro Amoedo, XII.1943, fr., O.C. Góes 831 (RB).

Material adicional examinado: BRASIL. RIO DE JANEIRO: Seropédica, 27.V.1961, fl., H. Monteiro Filho 3098 (RBR); Serra das Araras, 19.V.1936, fl., A.C. Brade 15230 (RB); Niterói, 19.I.1985, fl. e fr., A. Gentry \& E. Zardini 49726 (RBR).

Jacquemontia martii foi registrada no presente estudo na Floresta Ombrófila Densa Montana do Parnaso, porém, também é referida para formações de Floresta Ombrófila Aberta. Sua afinidade com J. blanchetti foi descutidada nos comentários desta espécie.

28. Jacquemontia velutina Choisy Prodr. 9: 398. 1845.

Fig. 6k

Trepadeira herbácea, tomentosa a fulvo-velutina. Lâmina 3-9 × 2-4,5 cm, cordiforme a ovada, base cordada a subcordada, ápice agudo a acuminado, apiculado. Inflorescência cima multiflora laxa. Cálice com sépalas levemente desiguais, 5-8 × 3-4 mm membranáceas, tomentosas a pubescentes, lanceoladas a ovadas, base redonda, ápice agudo, acuminado a apiculado, esverdeado, margem ocasionalmente ciliada, indumento frequentemente mais adensado nas sépalas externas; corola 1,3-1,8 cm compr., azulada a alvecente; Cápsula ovoide, 5-7 × 5-6 mm; semente 3-4 × 2-3 mm.

Material examinado: Petrópolis, Correias, Serra dos Órgãos, 22.VII.1970, fl. P. Carauta 1147 (RB); Petrópolis, Serra dos Órgãos, caminho para os castelos do Morro Açú, 30.XII.1968, fl., J.P.P. Carauta 700 (RB); Magé, Serra dos Órgãos, 11.VI.2009, fl. A.L.O. Moura 45 \& R.S. Nunes (RB); Silva Jardim, Reserva Biológica de Poço das Antas, 28.VII.2009, fl. e fr., A.L.O. Moura 61, G.V. Somner \& R.S. Nunes (RB). Material adicional examinado: BRASIL. MINAS GERAIS: Santa Rita de Jacutinga, 27.VII.1970, fl. e fr., P.L. Krieger 8974 (RB); São Paulo: Picinguaba, 2.X.1975, fl., D.S.D. Araujo 866 (RB).

Jacquemontia velutina é refererida para áreas de Floresta Atlântica em formações de Floresta Ombrófila Densa, Aberta e Mista. Neste estudo a espécie foi registrada em áreas de floresta Submontana e Montana do Parnaso e na Capoeira Aluvial da Rebio Poço das Antas.

A presença de indumento fulvo-velutino é bastante característica da espécie que também pode ser diferenciada de $J$. holosericea por apresentar sépalas levemente desiguais com ápice agudo a acuminado e apiculado.

Merremia Dennst. ex Endl. Gen. Pl. 1: 1403.1841.

Figs. 3p-s; 7

Trepadeiras herbáceas ou lenhosas, ou ocasionalmente erva rastejante com as porções apicais volúveis. Folha composta, digitada ou simples, inteira, cordada, palmada ou palmatissecta. Cálice com sépalas de tamanho desigual, imbricadas. Corola campanulada, glabra; estames iguais ou desiguais, inclusos, pubescentes na base dos filetes, antera frequentemente torcida após a antese; ovário súpero, glabro, estilete único, estigmas dois, globosos, papilosos. Fruto cápsula septifraga, globosa ou ovoide, 4-valvar, valvas glabras, cálice geralmente acrescente; sementes 4, endosperma abundante.

No Brasil ocorrem 17 espécies de Merremia, das quais 5 são endêmicas da flora brasileira (SimãoBianchini et al. 2015).

29. Merremia cissoides (Lam.) Hallier f., Bot. Jahrb. Syst. 16: 552. $1893 . \quad$ Figs. 3p; 7a,b

Trepadeira herbácea ou ocasionalmente erva rastejante com as porções apicais volúveis, pubescentes 
no caule, lâmina foliar e sépala (tricomas glandulares) e esparso-hirsutos no caule (tricomas simples). Tricomas glandulares do caule, densos, com base vinácea e os não glandulares, eretos, longos e esparsos. Folha composta, digitada; folíolo 0,8-2 $\times 0,2-0,6 \mathrm{~cm}$, ovado a lanceolado, base atenuada a acuminada, ápice obtuso a acuminado, apiculado, margem inteira, denteada, raro sinuada, venação craspedódroma. Flores solitárias ou em dicásio simples. Cálice com sépala 1,3-1,5 × 0,4-0,6 cm, cartácea, ovado-lanceolada, base arredondada a obtusa, ápice caudado; corola 1-1,3 cm compr., alva com fauce purpúrea; estames desiguais. Cápsula globosa, 6-8 × 6-7 mm; semente 2-3 × 2-3 mm, com tufos de tricomas não glandulares.

Material examinado: Silva Jardim, Reserva Biológica de Poço das Antas, Linha de trem, 29.VII.2009, fr., A.L.O. Moura 64, G.V. Somner \& R.S. Nunes (RB).

Material adicional examinado: BRASIL. RIO DE JANEIRO: Niterói, Jurujuba, 4.VI.1939, fl. e fr., A.C. Brade 16119 (RB).

Merremia cissoides apresenta ampla distribuição em todo território brasileiro. Na Floresta Atlântica a espécie ocorre em áreas de restinga e nas formações de Floresta Ombrófila Densa, Aberta e Mista. Neste estudo a espécie foi coletada em área antropizada na Rebio de Poço das Antas, a 21 m.s.m., como erva rastejante e os ramos com as extremidades volúveis.

Dentre os espécimes observados de $M$. cissoides, a maioria apresentou margem da lâmina foliar denteada e o tipo de margem sinuada foi menos frequente. $\mathrm{O}$ indumento constituído de tricomas simples e glandulares distingue $M$. cissoides das demais espécies do gênero Merremia registradas no presente estudo.

\section{Merremia dissecta var. edentata (Meisn.)} O`Donell. Lilloa 6: 505.1941. Fig. 7c-e

Trepadeira herbácea com tricomas dourados.

Caule com indumento hisurto a glabrescente. Folha simples 3,5-9 × 3,5-13,5 cm, pubescente a glabrescente, palmatissecta, 5-7 lobada, base hastada, ápice agudo a acuminado, mucronado, margem inteira, sinuada a denteada, venação basal. Flores solitárias ou em dicásios simples. Cálice com sépala 1,7-2,3 × 0,7-1 cm membranácea, lanceolada a ovada, base arredondada, ápice agudo a acuminado, apiculado; corola 3,5-4,5 cm compr., alva com a fauce amarelada; estames desiguais; estigma alvo. Cápsula ovoide, 1,7-2 × 1,2-1,3 cm; semente glabra, 5-6 × 4-5 mm.

Material examinado: Silva Jardim, Reserva Biológica de Poço das Antas, 2.IV.2009, fl. e fr., A.L.O. Moura 25 \& G.V. Somner (RB); Itaiaia, Parque Nacional de
Itatiaia, 22.IV.2009, fl. e fr., A.L.O. Moura et al. 36 (RB); Guapimirim: Parque Nacional da Serra dos Órgãos, 12.VII.2009, fl. e fr., A.L.O. Moura \& R.S. Nunes 50 (RB); Magé, Parque Nacional da Serra dos Órgãos, Santo Aleixo, 11.VI.2009, fl. e fr., A.L.O. Moura \& R.S. Nunes 43 (RB).

Merremia dissecta var. edentata é referida para áreas de Floresta Atlântica em formações de Floresta Ombrófila. No presente estudo registrou-se a ocorrência desta variedade nas três unidades: no Parnaso foi coletada na floresta Submontana nas altitudes de 110, 162 e 228 m.s.m, ascendendo em forófitos de 9, 32 e 15 cm de CAP respectivamente; no PNI foi encontrada na floresta Montana nas altitudes entre 640 e 800 m.s.m e nesta altitude observou-se a variedade ascendendo em forófito com $92 \mathrm{~cm}$. de CAP.; na Rebio Poço das Antas ocorre nas formações de Capoeira Aluvial a 28 m.s.m e na formação pioneira com influência aluvial a 19 m.s.m., em forófitos com 34 e 44 cm de CAP, respectivamente.

Na área da Rebio Poço das Antas, em formações de capoeira e na floresta Submontana, foram observados indivíduos de M. dissecta (A.L.O. Moura et al. 27, 56, 60, RB) que diferem de $M$. dissecta var. edentata pelo seguinte conjunto de caracteres: lâmina foliar palmatífida, levemente recortada em direção a base da folha, corola inteiramente alva e os estames iguais (Fig. 3q; Fig. 7f, g). A variedade típica, com ocorrência registrada para Mato Grosso e Mato Grosso do Sul (Simão-Bianchini \& Ferreira 2015) não apresenta o conjunto de caracteres citados. Estudos mais detalhados deverão ser realizados para verificar a validade de uma nova variedade para a espécie.

\section{Merremia macrocalyx (Ruiz \& Pav.) O’Donell, Lilloa 6. 506 (1941). $\quad$ Fig. 7h-j}

Trepadeira lenhosa, glabra, ramos jovens herbáceos, indumento glanduloso ausente. Folha composta, digitada, folíolo, 4,5-13,5 × 2,5-4 cm, membranácea, base atenuada, ápice agudo a acuminado, mucronado, margem inteira, lisa, venação broquidódroma, nervura da face abaxial pubescente. Inflorescência em dicásios compostos. Cálice com sépala 1,7-2,5 × 0,4-0,6 cm, cartácea, lanceolada, base redonda, ápice obtuso a retuso, apiculado; corola 3,8-4,5 cm compr., alva; estames desiguais. Cápsula globosa, 7-8 × 8-9 mm; semente 3-4 × 2-3 mm, pubescente.

Material examinado: Teresópolis, Serra dos Órgãos, 04.IV.1953, fl. e fr., E. Pereira 712 (RB); 11.III.2001, fl., C.B. Costa et al. 484 (SP); Petrópolis, Estrada do Contorno, 23.III.1968, fl. e fr., D. Sucre 2508 (RB).

Material adicional examinado: BRASIL. RIO DE JANEIRO: Guanabara, Ilha do Governador, Jardim 

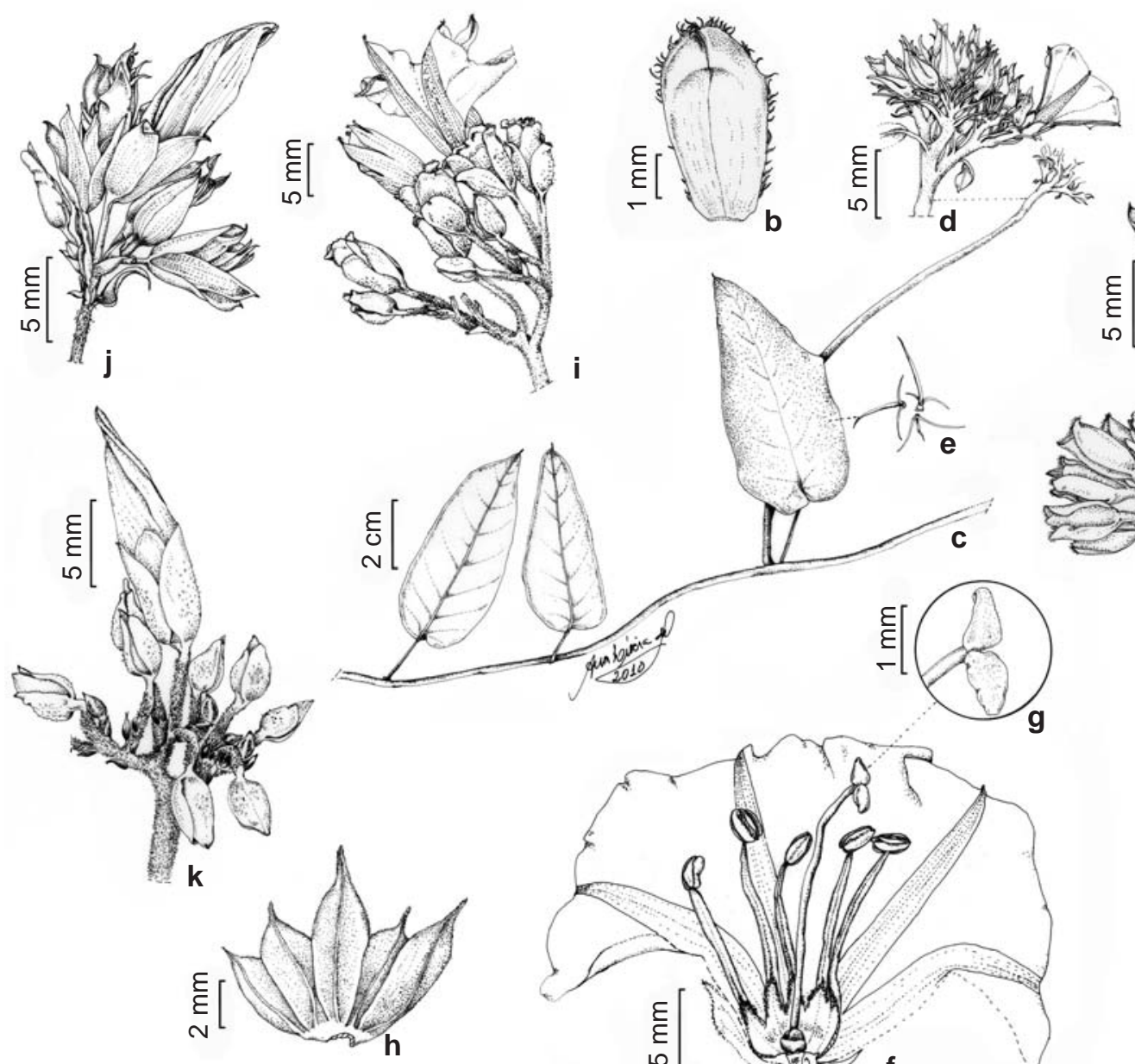

(1)
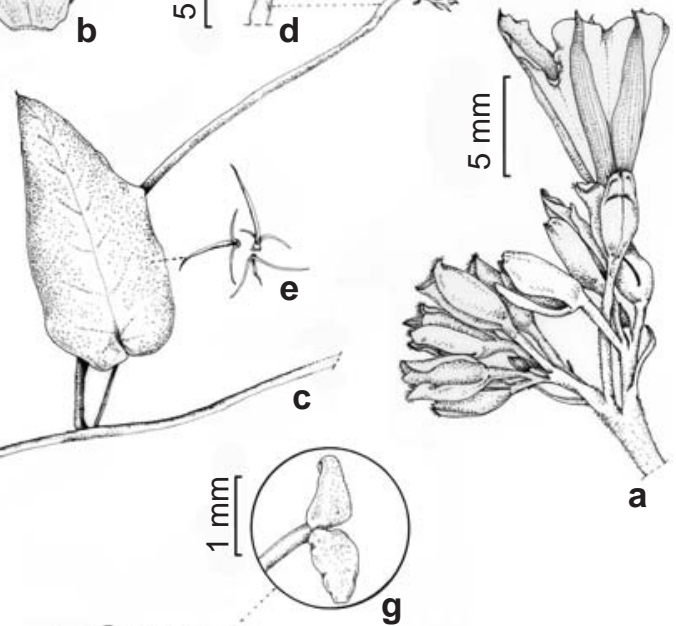

Figura 6-a,b. Jacquemontia blanchetti Moric.- a. inflorescência; b. sépala. c-h. Jacquemontia densiflora (Meisn.) Hallier f. - c. ramo florífero; d. inflorescência; e. tricoma estrelado; f. corte longitudinal da flor; g. detalhe do estigma oval-plano; h. cálice. i. Jacquemontia holosericea (Weinm.) O’Donell-inflorescência. j. Jacquemontia martii Choisyinflorescência. k. Jacquemontia velutina Choisy-inflorescência. (a-b. Forzza 3803; c-h. Moura \& Nunes 41; i. Braga 2714; j. Gentry \& Zardini 49726; k. Carauta 700).

Figure 6 - a,b. Jacquemontia blanchetti Moric.- a. inflorescence; b. sepal. c-h. Jacquemontia densiflora (Meisn.) Hallier f.- c. flowering branch; $d$. inflorescence; e. starred trichome; f. longitudinal slice of the flower; g. detail of the flat oval stigma; h. calyx. i. Jacquemontia holosericea (Weinm.) O’Donell-inflorescence. j. Jacquemontia martii Choisy-inflorescence. k. Jacquemontia velutina Choisy-inflorescence. (a-b Forzza 3803; c-h Moura \& Nunes 41; i. Braga 2714; j. Gentry \& Zardini 49726; k. Carauta 700).

Guanabara, 4.VI.1961, fl. e fr., G.V.J. Pabst 5630 (HB); Piraí, 24.IV.1991, fl. e fr., G.V. Somner \& M.V.L. Pereira 640 (RBR).

Merremia macrocalyx tem ampla distribuição ocorrendo em todas as regiões do território brasileiro. Na Floresta Atlântica é referida para formações de Floresta Ombrófila, incluindo áreas de Restinga e capoeiras e de Floresta Estacional Semidecidual. No presente estudo foi coletada na Floresta Ombrófila Densa Montana do Parnaso.
A espécie pode ser diferenciada de $M$. cissoides pela ausência de tricoma glandular no indumento e por apresentar pelas lâminas foliares com margem lisa e venação broquidódroma.

32. Merremia tuberosa (L.) Rendle, Fl. Trop. Afr. 4(2): 104. 1905.

Figs. 3r; 7k

Trepadeira lenhosa, glabra. Folha simples 4,5-11,5 × 5,5-12 cm, palmatissecta, 5-7 lobada, membranácea, base hastada, ápice agudo, apiculado, 


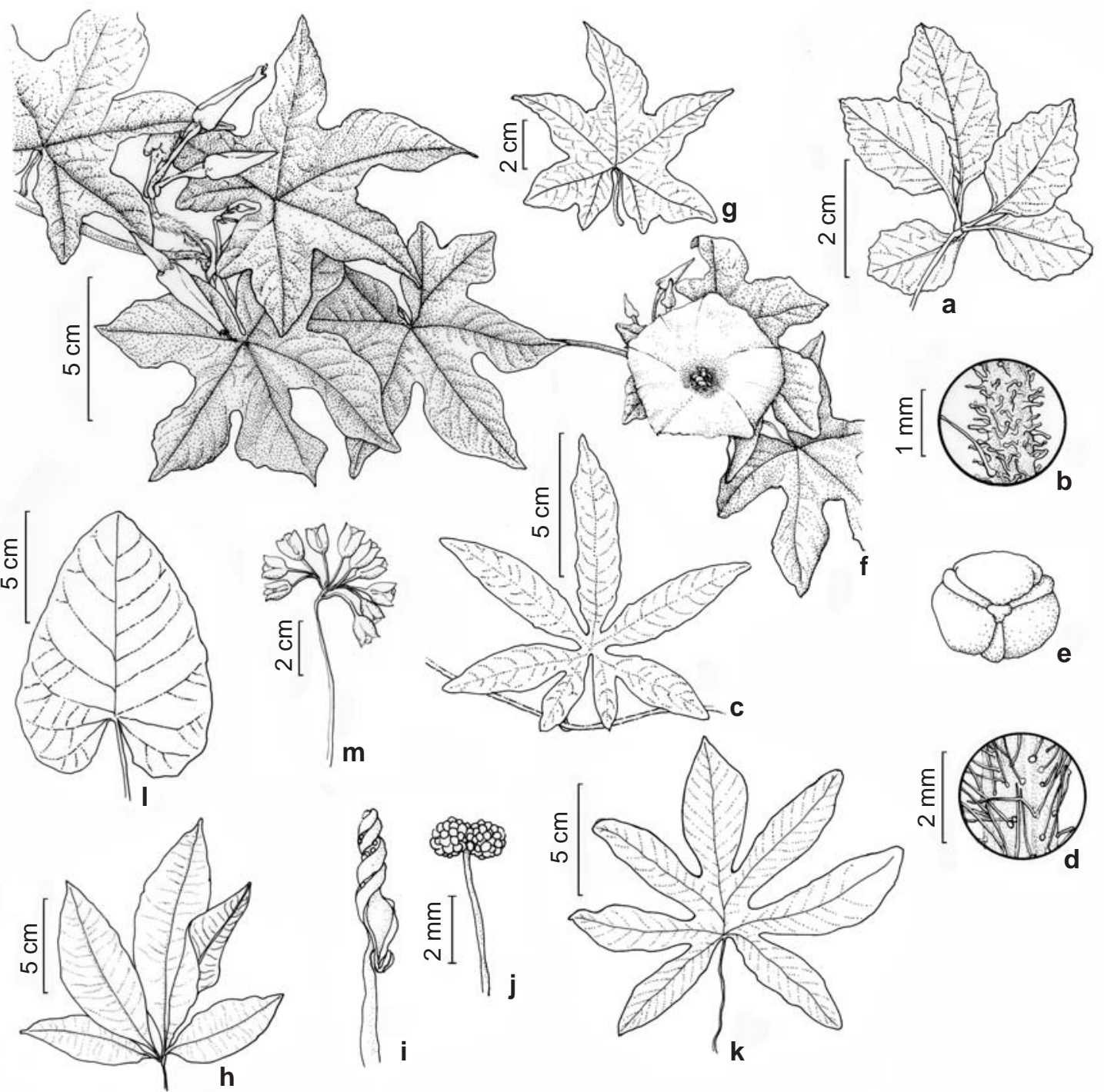

Figura 7 - a, b. Merremia cissoides (Lam.) Hallier f.-a. folha; b. detalhe dos tricomas glandulosos. c-e Merremia dissecta var. edentata (Meisn.) O`Donell.-c. folha; d. detalhe do indumento hisurto; e. pólen; f, g. Merremia dissectaf. ramo florífero; g. folha. h-j. Merremia macrocalyx (Ruiz \& Pav.) O’Donell - h. folha; i. antera; j. estigma. k. Merremia tuberosa (L.) Rendle-folha. 1, m. Merremia umbellata (L.) Hallier f. - 1. folha; m. infrutescência. (a, b. Moura et al. 64; c-e. Moura 25; f, g. Moura et al. 27; h-j. Costa 484; k. Moura et al. 52; 1, m. Moura et al. 63).

Figure 7 -a, b. Merremia cissoides (Lam.) Hallier f. - a. leaf; b. detail of the glandulous trichomes. c-e. Merremia dissecta var. edentata (Meisn.) O`Donell. - c. leaf; d. detail of the hisurte covering; e. polen. f, g. Merremia dissecta -f. flowering branch; g. leaf. h-j. Merremia macrocalyx (Ruiz \& Pav.) O’Donell - h. leaf; i. anther; j. stigma. k. Merremia tuberosa (L.) Rendle-leaf. 1, m. Merremia umbellata (L.) Hallier f. - 1. leaf; m. infructescence. (a, b. Moura et al. 64; c, d. Moura et al. 27; e-g. Moura 25; h-j. Costa 484; k. Moura et al. $52 ; 1, \mathrm{~m}$. Moura et al. 63).

margem repandida, venação basal. Inflorescência em dicásios simples. Cálice com sépala 2,3-2,7 $\times 0,6-1,2 \mathrm{~cm}$, membranácea, lanceolada a ovada, base arredondada, ápice agudo; corola $4-4,5 \mathrm{~cm}$ compr., amarelada; estames desiguais. Cápsula ovoide, 3-3,5 × 2,3-2,5 cm, cálice acrescente e enrijecido; semente 1,5-1,8 × 1-1,2 cm, pubescente com tricomas negros.

Material examinado: Guapimirim, Espinhaço, 12.VII.2009, fr., A.L.O. Moura \& R.S. Nunes 52 (RB); Silva Jardim, Trilha para Fazenda Portuense, 13.VII.1994, fl. e fr., H.C. Lima 4939 (RB); Silva Jardim: Estrada para a casa do Aristides, 25.I.1995, fl. e fr., J.M.A. Braga 1827 (RB). 
Material adicional examinado: BRASIL. RIO DE JANEIRO: Ilha de Paquetá, 29.VII.1964, fr., F. Torgo (HB 32432).

Merremia tuberosa é uma espécie naturalizada referida para áreas de Floresta Atlântica em formações de Floresta Ombrófila, estabelecendose também em áreas antropizadas. Neste estudo a espécie foi registrada na floresta Submontana do Parnaso a 148 m.s.m, ascendendo em um forófito de $33 \mathrm{~cm}$ de CAP e na Capoeira Submontana na Rebio Poço das Antas.

Conhecida popularmente como "flor-depau”, devido à característica do fruto, onde o cálice lignificado e acrescente, cerca de $3 \mathrm{~cm}$ a mais no seu comprimento, lembra uma flor de madeira. Outras características marcantes de $M$. tuberosa são a corola amarelada e as sementes pubescentes com tricomas negros.

33. Merremia umbellata (L.) Hallier f., Bot. Jahrb. Syst. 16(4-5): 552. 1893.

Figs. 3s; 7l,m

Trepadeira herbácea, pubescente a glabrecente, com tricomas dourados a alvacentos. Folha simples 4,5-9,5 × 4-8 cm, cordada a deltoide, base cordada, subcordada, sagitada ou truncada, ápice agudo a acuminado, apiculado, margem inteira, venação bronquidródoma. Inflorescência em cima umbeliforme. Cálice com sépala 0,8-1× 0,5-0,8 cm, cartácea, oval, ovada ou oboval, base arredondada a obtusa, ápice arredondado, obtuso ou retuso; corola 2-2,2 cm compr., amarela; estames desiguais; estigmas esverdeados. Cápsula ovoide, maior que o cálice, $0,6-0,8 \times 1-1,2 \mathrm{~cm}$, semente 4-5 × 3-4 mm.

Material examinado: Itatiaia, Parque Nacional de Itatiaia, 30.V.2009, fl., A.L.O. Moura 39 (RB); Silva Jardim, Reserva Biológica de Poço das Antas, 28.VII.2009, fl. e fr., A.L.O. Moura, G.V. Somner \& R.S. Nunes 63 (RB).

Material adicional examinado: BRASIL. RIO DE JANEIRO: Rio Bonito, 26.IX.1964, fr., Z.A. Trinta 909 \& E. Fromm 1985 (HB).

Merremia umbellata tem ampla distribuição no Brasil, ocorrendo desde a região Norte até a região Sul, em diferentes formações vegetacionais e em áreas antropizadas. No presente estudo a espécie foi coletada na floresta Montana do PNI a 680 m.s.m., ascendendo em um forófito de $5 \mathrm{~cm}$ de CAP e na Rebio Poço das Antas nas formações de Capoeira Aluvial em altitudes de 8 e 28 m.s.m, em forófitos com CAP de 2 e 3 cm, respectivamente, e na Capoeira Submontana a 14 e 17 m.s.m, em forófitos com CAP de 1,2 e 5 cm respectivamente.
Merremia umbellata é bastante distinta das demais espécies do gênero Merremia registrada para as áreas de estudo, principalmente por apresentar folhas simples e inflorescência em cima umbeliforme.

\section{Agradecimentos}

À Capes, a bolsa de Mestrado concedida à primeira autora no Programa de Pós Graduação em Botânica do Instituto de Pesquisas Jardim Botânico do Rio de Janeiro; aos administradores das Unidades de Conservação onde foi realizado o trabalho; aos curadores dos herbários consultados; a Dr ${ }^{\mathrm{a}}$ Genise Vieira Freire e a Dr ${ }^{\mathrm{a}}$ Neusa Tamaio, o apoio nas expedições de campo e sugestões na primeira versão do manuscrito; e a Dr ${ }^{\mathrm{a}}$ Rosângela Simão-Bianchini, a revisão das espécies tratadas neste estudo.

\section{Referências}

Acevedo-Rodríguez, P. 2005. Vines and climbing plants of Puerto Rico and the Virgin Islands.Contributions from the United States National Herbarium 51: 1-483.

Aguiar, A.P.; Chiarello, A.G.; Mendes, S.L. \& Matos, E.N. 2005. Os corredores Central e da Serra do Mar na Mata Atlântica Brasileira. In: Galindo-Leal, C. \& Câmara, I.G. (eds). Mata Atlântica: biodiversidade, ameaças e perspectivas. S.O.S. Mata Atlântica e Conservação Internacional, Belo Horizonte. Pp. 119-132.

Austin, D.F. 1975. Convolvulaceae. In: Flora of Panamá. Annals of Missouri Botanical Garden 62: 157-224.

Austin D.F. 1980. Convolvulaceae. In: Dassanayake M.D. \& Fosberg, F.R. (eds.). A revised hand book to the Flora of Ceylon. Amerind Publishing Co. Pvt. Ltd., New Delhi. Pp. 288-363.

Austin, D.F. 1986. Nomenclature of the Ipomoea nil complex (Convolculaceae). Taxon 35: 355-358.

Austin, D.F. 1998. The indiscriminate vector: human distribution of Dichondra micrantha (Convolvulaceae). Economic Botany 52:88-106.

Austin, D.F. \& Cavalcante, P.B. 1982. Convolvuláceas da Amazônia. Publicações Avulsas do Museu Goeldi 36: 1-134.

Barros, A.A.M.; Ribas, L.A. \& Araújo, D.S.D. 2009. Trepadeiras do Parque Estadual da Serra da Tiririca, Rio de Janeiro, Brasil. Rodriguésia 60: 1-14.

Bianco, S.; Bianco, M.S.; Pavani, M.C.M.D. \& Duarte D.J. 2007. Estimativa da área foliar de Ipomoea hederifolia L. e Ipomoea nil Roth. usando dimensões lineares do limbo foliar. Planta daninha 25: 325-329.

Cronemberger, C. \& Castro, E.B.V. 2007. Ciência e conservação na Serra dos Órgãos. Instituto Chico Mendes de Conservação da Biodiversidade. Ibama, Brasília, Distrito Federal. 298p. 
Davis, E.G. \& Naghettini, M.C. 2000. Estudo de chuvas intensas no estado do Rio de Janeiro. $2^{\text {a }}$ ed. Revista Ampliada. CPRM/Serviço Geológico do Brasil, Brasília. 140p.

Deuber, R. 1992. Ciência das plantas daninhas: fundamentos. FUNEP, Jaboticabal. 431p.

Engel, V.L.; Fonseca, R.C.B. \& Oliveira, R.E. 1998. Ecologia de lianas e manejo de fragmentos florestais. Série técnica IPEF 12: 43-64.

Falcão, J.I.A. 1957. Flora do Itatiaia I. Convolvulaceae. Rodriguésia 20: 62-64.

Falcão, J.I.A. 1974. As espécies brasileiras do gênero Dichondra Foster (Convolvulaceae). Rodriguésia 26: 135-142.

Falcão, J.I.A. 1977. Contribuição ao estudo das Convolvuláceas da Bahia. Rodriguésia 29: 41-102.

Falcão, W.F.A. \& Falcão, J.I.A. 1979. Convolvuláceas do Rio de Janeiro. Rodriguésia 31: 7-35.

Filgueiras, T.S.; Brochado, A.L.; Nogueira, P.E. \& Guala, G.F. 1994. Caminhamento - Um método expedito para levantamentos florísticos qualitativos. Caderno de Geociências 12: 39-43.

Franco, S.A.; Parada, G.L.; Viana, M. \& Quiroga, M. 2009. Tolerancia de Dichondra sericea (Swartz.) en distintas concentracions de meatales pesados. Avances en Energías Renovables y Medio Ambiente Vol. 13. Impreso en la Argentina. Pp. 103-106.

Gentry, A.H. 1991. The distribution and evolution of climbing plants. In: F.E. Putz \& H.A. Mooney (eds.). The Biology of Vines. Cambridge University Press, Cambridge. Pp. 3-49.

Giulietti, A.M.; Rapini, A.; Andrade M.J.G.; Queiroz, L.P. \& Silva, J.M.C. (orgs.). 2009. Plantas raras do Brasil. Conservação Internacional, Belo Horizonte. $496 \mathrm{p}$.

Guedes-Bruni, R.R.; Morim, M.P.; Lima, H.C. \& Sylvestre, L.S. 2002. Inventário florístico. In: Sylvestre, L.S. \& Rosa, M.M.T. (eds.). Manual metodológico para estudos botânicos na Mata Atlântica. Edur, Seropédica. Pp. 24-50.

Groth, D. 1984. Caracterização morfológica das plântulas e das sementes de três espécies daninhas da cultura de soja. In: Seminário Nacional de Pesquisa de Soja, 3, Campinas, Anais. EMBRAPA/Centro Nacional de Pesquisa de Soja, Campinas. Pp. 575-86.

Groth, D. 2001. Caracterização morfológica de sementes de espécies invasoras da família Convolvulaceae Juss. Revista Brasileira de Sementes 23: 1-13.

Harper, K.A.; Macdonald, S.E.; Burton, P.J.; Chen, J.; Brosofske, K.D.; Sanders, S.C.; Euskirchen, E.S.; Roberts, D. \& Esseen, P.A. 2005. Edge influence on forest structure and composition in fragmented landscapes. Conservation Biology 19: 768-782.

Hsu, T.W.; Wang, K.H. \& Chiang, T.Y. 2006. Ipomoea purpurea (L.) Roth (Convolvulaceae). A Species of the I. nil Complex, Newly Naturalized in Taiwan. BioFormosa 41: 19-22.
IBDF; FBCN. 1980. Plano de manejo do Parque Nacional da Serra dos Órgãos. Instituto Brasileiro de Desenvolvimento Florestal e Fundação Brasileira para Conservação da Natureza, Brasília. 173p.

Instituto Chico Mendes de Conservação da Biodiversidade - ICMBIO. 2012. PARNA Itatiaia. Disponível em $<$ http://www.icmbio.gov.br/portal/biodiversidade/ unidades-de-conservacao/biomas-brasileiros/ mata-atlantica/unidades-de-conservacao-mataatlantica/2181-parna-de-itatiaia.html>. Acesso em 18 dezembro de 2012.

Lima, H.C.; Lima, M.P.M.; Vaz, A.M.S.F. \& Pessoa, S.V.A. 1997. Trepadeiras da Reserva ecológica de Macaé de Cima. In: Lima, H.C. \& Guedes-Bruni, R.R. (eds.). Serra de Macaé de Cima: Diversidade Florística e Composição em Mata Atlântica. Jardim Botânico do Rio de Janeiro, Rio de Janeiro. Pp. 75-87.

Lima, H.C.; Pessoa, S.V.A.; Guedes-Bruni, R.R.; Moraes, L.F.D.; Granzotto, S.V.; Iwamoto, S. \& Ciero, J.D. 2006. Caracterização fisionômicoflorística e mapeamento da vegetação da Reserva Biológica de Poço das Antas, Silva Jardim, Rio de Janeiro, Brasil. Rodriguésia 57: 369-389.

Lorenzi, H. 2008. Plantas daninhas do Brasil: terrestres, aquáticas, parasitas e tóxicas. $4^{\mathrm{a}}$ ed. Instituto Plantarum, Nova Odessa. 640p.

Kissman, K.G. \& Groth, D. 1992. Plantas infestantes e nocivas. Basf, São Paulo. 798p.

MMA. 2008. Ministério do Meio Ambiente, Brasil. Lista Oficial das Espécies da Flora Brasileira Ameaçadas de Extinção. Instrução Normativa ${ }^{\circ}$ 6, de 23 de Setembro de 2008. Diário Oficial da União 185 , seção 1, 24 de Setembro de 2008. Diário Oficial da União, Brasília. Pp. 75-83.

Morim, M.P. 2006. Leguminosae arbustivas e arbóreas da Floresta Atlântica do Parque Nacional do Itatiaia, sudeste do Brasil: padrões de distribuição. Rodriguésia 57: 27-45.

Nagata, K.M. 1971. Hawaiian medicinal plants. Economic Botany 25: 245-254.

O’Donell, C.A. 1952. Convolvuláceas americanas nuevas o críticas III. Arquivos do Museu Paranaense 9: 207- 244.

Pastore, M. 2014. O gênero Jacquemontia Choisy (Convolvulaceae) no Estado de São Paulo, Brasil. Dissertação de Mestrado. Instituto de Botânica da Secretaria do Meio Ambiente do estado de São Paulo, São Paulo. 123p.

Putz, F.E. 1984. The natural history of lianas on Barro Colorado Island, Panama. Ecology 65:1713-1724.

Ribeiro, J.E.L.S. \& Bianchini, R.S. 1999. Convolvulaceae In: Ribeiro, J.E.L.S.; Hopkins, Vicentini, M.J.G.; A.; Sothers, C.A.S.; Costa, M.A.S.; Brito, J.M.; Souza, M.A.D.; Martins, L.H.P.; Lohman, L.G.; Assunção, P.A.C.L.; Pereira, E.C.; Silva, C.F.; Mesquita, M.R. \& Procópio, L.C. (eds.). Flora da Reserva Duck: Guia de identificação das plantas vasculares de uma 
floresta de terra-firme na Amazônia Central. Utrecht, INPA, Manaus. Pp. 588-591.

Simão-Bianchini, R. 1998. Ipomoea L. (Convolvulaceae) no Sudeste do Brasil. Tese de Doutorado.Universidade de São Paulo, São Paulo. 476p.

Simão-Bianchini, R. 1999. Jacquemontia revoluta (Convolvulaceae), a new species from Minas Gerais, Brazil. Taxon 9: 104-106.

Simão-Bianchini, R.; Ferreira, P.P.A. \& Pastore, M. Convolvulaceae. In: Lista de Espécies da Flora do Brasil. Jardim Botânico do Rio de Janeiro. Disponível em $<$ http://floradobrasil.jbrj.gov.br/jabot/ floradobrasil/FB93>. Acesso em 23 março 2015.

Simão-Bianchini, R. \& Ferreira, P.P.A. Ipomoea. In: Lista de Espécies da Flora do Brasil. Jardim Botânico do Rio de Janeiro. Disponível em $<$ http://floradobrasil. jbrj.gov.br/jabot/floradobrasil/FB126374>. Acesso em 21 abril 2015.

Stehmann J.R.; Forzza, R.C.; Sobral, M.; Salino, A. \& Kamino, L.H.Y. 2009. In: Plantas de Floresta Atlântica. Jardim Botânico do Rio de Janeiro. Disponível em < www.icb.ufmg.br/bot/mataatlantica/ projeto.htm>. Acesso em 13 outubro 2012.

Staples, G. 2012. Convolvulaceae - the morning glories and bindweeds. Disponível em $<$ http:// convolvulaceae.myspecies.info/node/9>. Acesso em 16 março de 2015.
Thiers, B. [continuamente atualizado]. Index Herbariorum. A global directory of public herbaria and associated staff. New York Botanical Garden’s Virtual Herbarium. Disponível em <http::// sweetgum. nybg.org/ih/>. Acesso em 16 março 2015.

Thomas, T.G.; Rao, S. \& Lal, S. 2004. Mosquito larvicidal properties of essential oil of an indigenous plant, Ipomoea cairica Linn. Japanese Journal of Infectious Diseases 57: 176-7.

Vaz, A.M.S.F. 1992. Diversidade de plantas vasculares da floresta atlântica do Rio de Janeiro. Boletim do Museu de Biologia Mello Leitão 1: 77-82.

Vaz, A.M.S.F. \& Vieira, C.M. 1994. Identificação de famílias com espécies trepadeiras. In: Lima, M.P.M. \& Guedes-Bruni, R.R. (eds.). Reserva Ecológica de Macaé de Cima, Nova Friburgo, RJ. Aspectos florísticos das espécies vasculares. Vol. 1. Jardim Botânico do Rio de Janeiro, Rio de Janeiro. Pp. 75-82.

Veloso, H.P.; Rangel Filho, A.L.R. \& Lima, J.C.A. 1991. Classificação da vegetação brasileira, adaptada a um sistema universal. Instituto Brasileiro de Geografia e Estatística, Rio de Janeiro. 116p.

Werneck, M.S.; Sobral, M.E.G.; Rocha, C.T.V.; Landau, E.C. \& Stehmann, J.R. 2011. Distribution and endemism of angiosperms in the Atlantic Forest. Natureza \& Conservação 9: 188-193. 
